\title{
Unanimity and Disagreement on the Supreme Court
}

\section{Citation}

Cass R. Sunstein, Unanimity and Disagreement on the Supreme Court, 100 Cornell L. Rev. 769 (2015).

\section{Published Version}

http://cornelllawreview.org/files/2015/05/Sunsteinfinal.pdf;http://cornelllawreview.org/articles/ unanimity-and-disagreement-on-the-supreme-court/

\section{Permanent link}

http://nrs.harvard.edu/urn-3:HUL.InstRepos:16153250

\section{Terms of Use}

This article was downloaded from Harvard University's DASH repository, and is made available under the terms and conditions applicable to Open Access Policy Articles, as set forth at http:// nrs.harvard.edu/urn-3:HUL.InstRepos:dash.current.terms-of-use\#OAP

\section{Share Your Story}

The Harvard community has made this article openly available.

Please share how this access benefits you. Submit a story.

Accessibility 


\title{
Preliminary draft $7 / 21 / 2014$ \\ Subject to significant revision \\ All rights reserved
}

\section{Unanimity and Disagreement on the Supreme Court}

\author{
Cass R. Sunstein*
}

\begin{abstract}
In 2013, the Supreme Court showed an unusually high rate of unanimous decisions - the highest, in fact, since 1940. This increase in unanimity, long favored by Chief Justice John Roberts, places a spotlight on an insufficiently appreciated fact: In 1941, the Supreme Court experienced a radical transformation. Almost immediately, it changed from a court that had operated by consensus, with very few separate opinions, into something closer to nine separate law offices, with a large number of dissenting opinions and concurrences, and with a significant rate of 5-4 divisions. Remarkably, the patterns established in the early 1800s continued until 1941, and the patterns established in the early 1940s have persisted to the present day. The transformation of 1941 appears to be attributable, in significant part, to the leadership style of Chief Justice Harlan Fiske Stone, who had no aversion to separate opinions and split decisions, and who was a frequent dissenter himself. The transformation offers general lessons not only about consensus and dissent within courts, but also about broader relationships among leaders, personnel, path dependence, prevailing norms, and the Court's future. With respect to group behavior, it suggests the possibility of multiple equilibria: With small differences in leadership style and prevailing norms, the level of publicly expressed dissent can either grow or wither. With respect to the normative issues, the standard arguments in favor of a higher level of consensus within the Court - pointing to the values of legitimacy, stability, and minimalism - rest on fragile empirical foundations. It is true that a badly fractured Supreme Court can create uncertainty, and that internal divisions have costs as well as benefits, but there is no sufficient reason to hope for a return to the pre-1941 patterns.
\end{abstract}

\section{Introduction}

\footnotetext{
* Robert Walmsley University Professor, Harvard University. I am grateful to Mary Schnoor for superb comments and indispensable research assistance, above all with the statistical analysis. Thanks as well to Jon Elster, Noah Feldman, Jane Mansbridge, Martha Minow, Eric Posner, Mark Tushnet, and Adrian Vermeule for valuable comments.
} 
It is common to notice, and sometimes to deplore, ${ }^{1}$ the absence of consensus on the Supreme Court. On many of the great issues of the day, the Court has been divided 5-4. ${ }^{2}$ Explicitly concerned about the problem of legitimacy, Chief Justice John Roberts suggested in 2006 that the Court should reorient itself in the direction of greater unanimity and fewer separate opinions. ${ }^{3}$ The Chief Justice contended that "the most successful chief justices help their colleagues speak with one voice." ${ }^{4}$ In his view, "Unanimous, or nearly unanimous, decisions are hard to overturn and contribute to the stability of the law and the continuity of the Court; by contrast, closely divided, 5-4 decisions make it harder for the public to respect the Court as an impartial institution that transcends partisan politics." ${ }^{5}$

Under his leadership, however, there has not been a reorientation toward unanimity. In general, the patterns that concerned the Chief Justice in 2006 have been maintained. ${ }^{6}$ The only exception is the 2013 term, which saw an apparent shift in the direction that he favored, with an unusually high percentage of unanimous cases, and a correspondingly significant decrease in dissenting opinions. In both cases, the relevant rates were the lowest since 1940. It remains to be seen whether the 2013 term is an outlier or instead a harbinger of an emerging norm toward higher levels of consensus.

In this Article, I have three goals. The first is to offer an account of voting patterns within the Supreme Court over time. As we shall see, it is only a modest oversimplification to say that the Court has had two eras, divided by a single year: 1941. Before that year, the Court was overwhelmingly likely to decide cases without either dissents or separate concurrences, and 5-4 divisions were exceedingly rare. Between 1801 and 1940, the relevant patterns were essentially identical. After 1941, dissents and concurrences suddenly became routine, and 5-4 divisions became unremarkable. Between 1941 and the present, the relevant numbers have not greatly changed (with the partial exception of 2013). It is not an overstatement to say that in certain important respects, the modern Supreme Court was born in 1941.

\footnotetext{
${ }^{1}$ See Adam Liptak, "The Polarized Court", N.Y. Times, The Upshot (May 10, 2014), available at http://www.nytimes.com/2014/05/11/upshot/the-polarized-court.html.

${ }^{2}$ See, e.g., Citizens United v. FEC, 558 U.S. (2010); Hobby Lobby, U.S. (2014); Shelby County v. Holder, 570 U.S. (2013).

${ }^{3} \mathrm{http}: / / \mathrm{www}$. theatlantic.com/magazine/archive/2007/01/robertss-rules/305559/

${ }^{4}$ Id.

${ }^{5}$ Id. Note that in the civil law tradition, opinions are announced without dissents, and hence opinions give the appearance of unanimity. See Ruth Bader Ginsburg, The Role of Dissenting Opinions, 95 Minn L Rev 1, 2 (2010), and consider this suggestion: "In civil-law systems, the nameless, stylized judgment, and the disallowance of dissent are thought to foster the public's perception of the law as dependably stable and secure." Id. at 3.

${ }^{6}$ See infra Figures 11-13.
} 
These remarkable patterns are known among political scientists, who initially established their existence, ${ }^{7}$ but they are not widely appreciated within the legal culture. They should be, with the aid of statistical analysis. ${ }^{8}$ As we shall see, an understanding of the patterns has broad implications for thinking not only about the Supreme Court, but also about the role of institutional leaders, the emergence and revision of norms, ${ }^{9}$ and the conditions for multiple equilibria in law and politics.

My second goal is to explain those patterns, including the rise of the norm of consensus, the shift in 1941, and the relative stability of the post-1941 period. Was the pre-1941 period a kind of imposition, brought about largely by the force of tradition and the persuasiveness and authority of relevant Chief Justices, above all Chief Justice John Marshall? And what explains the sudden transformation -- and the fact that it has proved robust? If we exercised our imaginations, we could envision a court - in, say, 1970, or 1980, or 2015 - that returned to the patterns of the pre1941 era. The fact that to date, such a court belongs to the realm of the imagination requires a separate explanation. My basic account emphasizes two factors: path dependence and institutional culture. ${ }^{10}$ Chief Justice Marshall played the crucial role in establishing the original norm of consensus, and Chief Justice Harlan Fiske Stone played a corresponding role in eliminating that norm. Without these two chief justices, different paths are entirely imaginable. ${ }^{11}$ But after both of them left the bench, institutional culture, and the norms for which they were largely responsible, became exceedingly important.

\footnotetext{
${ }^{7}$ The original treatment is C. HeRMAn PRITCHETt, THE RoOSEVELt COURT: A STUDY IN Judicial Politics AND VALUES, 1937-1947 (1948); Pritchett noticed that "the 1941-42 term was definitely a turning point for the Roosevelt Court." Id. at 40. In my view, the best discussion remains Thomas Walker et al., On the Mysterious Demise of Consensual Norm in the United States Supreme Court, 50 J Politics 361 (1988). I owe a particular debt to that discussion here. A exceedingly valuable, recent treatment is PAMELA C. CORLEY ET AL., THE PUZZLE OF UNANIMITY (2013); a relevant part of that discussion can be found in Pamela C. Corley et al., Revisiting the Roosevelt Court: The Critical Juncture from Consensus to Dissensus, 38 J. of Supreme Court Hist. 20 (2013).

${ }^{8}$ One of my principal goals here, in fact, is to provide some tests of the significance of apparent changes over time. (See Appendix for relevant details.) Analyses of any such changes, and of differences in voting patterns among the justices, greatly benefit from use of such tests, because some apparently noteworthy changes and differences turn out to be insignificant in the light of small sample sizes.

${ }^{9}$ For valuable discussion, with implications for the practices discussed here, see EDNA UlLMANN-MARGALIT, THE EMERGENCE OF NORMS (1977); Edna Ullmann-Margalit, Revision of Norms, 100 Ethics 756 (1990); CRISTINA BICCIERI, THE GRAMMAR OF SOCIETY: THE NATURE AND DYNAMICS OF SOCIAL NORMS (2005).

10 "Culture" should not, of course, be taken as a black-box; it must be explained by reference to the beliefs and actions of individuals. See infra (emphasizing the assessments of particular justices about whether to write separately).

${ }^{11}$ These conclusions attest to certain arguments about the inevitability of counterfactual history and the tight connection between causal claims and claims about causation. See JON ELSTER, LOGIC AND SOCIETY 176 (1978).
} 
My third goal is to evaluate the post-1940 status quo, in which we see frequent separate opinions and a high rate of 5-4 decisions (on average, about 17 percent annually). Those who approve of the pre-1941 norm defend their view by reference to the values of institutional credibility, stability, and minimalism. As we shall see, however, their arguments depend on empirical assumptions that are unlikely to hold true. At least in general, there is no good reason to believe that the post-1941 patterns are a significant problem for the Court in particular or for the nation in general.

\section{The Transformation of 1941}

For orientation, here are three graphs that show the rates of dissents, concurrences, and divisions by one-vote margin (5-4 or 4-3) from 1801 through 2013. ${ }^{12}$ The essential picture is immediately clear. It is as if the United States has had two courts, operating in accordance with different norms. Something quite dramatic happened in the early 1940s, and in particular, 1941 marks the beginning of the transformation. ${ }^{13}$

\footnotetext{
${ }^{12}$ All numbers from 1801-2009 are from Lee Epstein, Jeffrey A. Segal, Harold J. Spaeth, \& Thomas G. Walker, The Supreme Court Compendium: Data, Decisions, and Developments, $5^{\text {th }}$ Ed. (2012). Numbers from 2010-2012 are from Harold J. Spaeth, Sara Benesh, Lee Epstein, Andrew D. Martin, Jeffrey A. Segal, and Theodore J. Ruger. 2013. Supreme Court Database, Version 2013 Release 01. URL: http://supremecourtdatabase.org. Last accessed: July 12, 2014. Numbers from the 2013 term were collected by the author. As used here, the rate of dissent is the percentage of total opinions in a term that contain one or more dissenting opinions; the rate of concurrence is the percentage of total opinions in a term that contain one or more concurring opinions; and the rate of cases decided by a one-vote margin is the percentage of the total cases decided by a 5-4 or 4-3 split. The total opinions in a term is taken to be all full written opinions, in addition to per curiam opinions following oral argument.

${ }^{12}$ See West Coast Hotel v. Parrish, 300 U.S. 379 (1937).

${ }^{13}$ For a similar conclusion, but with an emphasis on the importance of the immediately subsequent years as well, see Corley et al., Revisiting, supra note.
} 

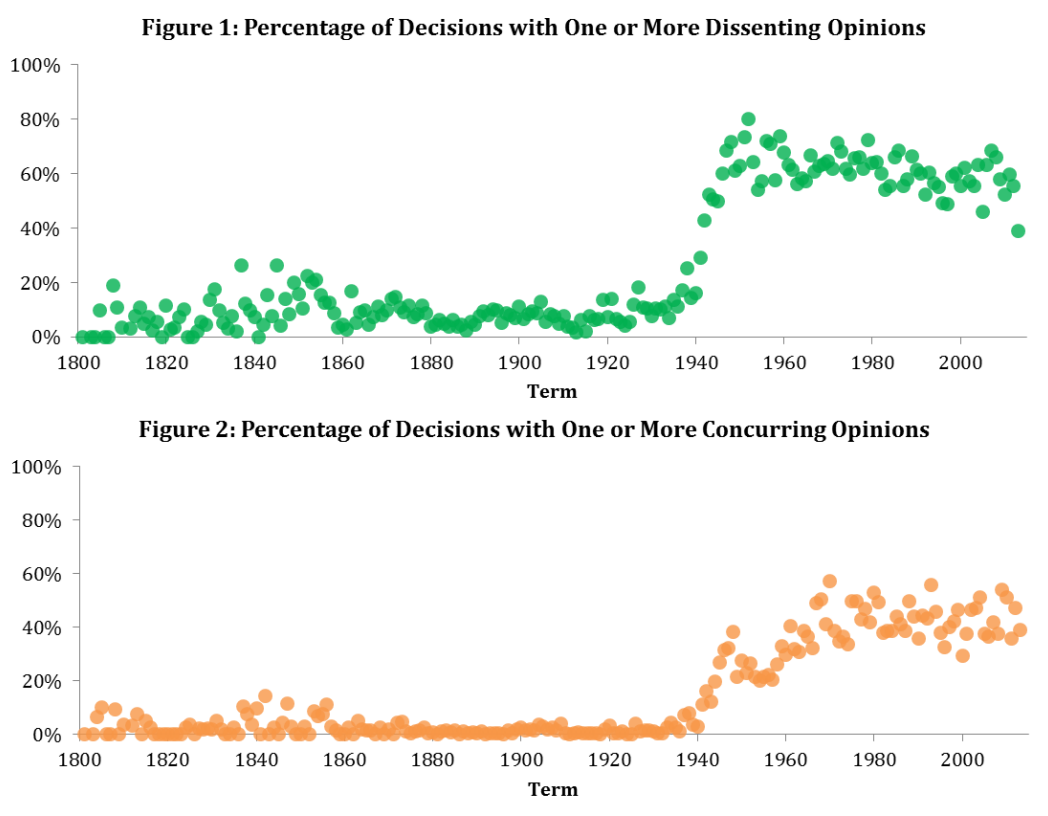

Figure 3: Percentage of Cases Decided by One-Vote Margin

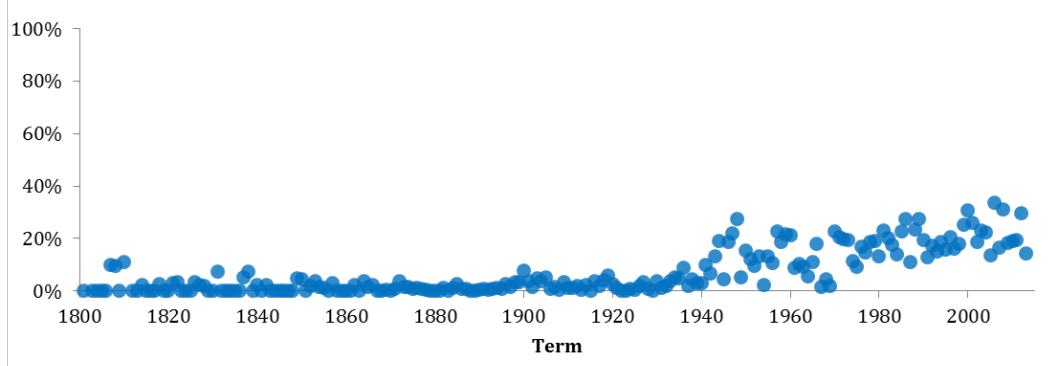

It is particularly puzzling that the breakdown of consensus occurred not during but in the aftermath of a period in Supreme Court history that is thought to be one of particular contestation, and that famously split the justices. From 1905 until 1937, the Court was engaged in a series of intense contests with the executive branch, especially on constitutional questions involving the kinds of regulations associated with the New Deal and Progressive Eras. The period between 1905 and 1937, often described as the Lochner era, was one in which the Court frequently struck down important legislation, and indeed, those years produced some of the most important, and most energetic, dissenting opinions in the Court's history. ${ }^{14}$ Notably, however, the norm of consensus was very much in force. In 1910, for example, 89

\footnotetext{
${ }^{14}$ See, e.g., Lochner v. New York, 198 U.S. 45, 74 (1905) (Holmes, J., dissenting); Adkins v. Children's Hospital, 261 U.S. 525, 567 (1923) (Holmes, J., dissenting).
} 
percent of the Court's decisions were unanimous, ${ }^{15}$ and between 1911 and 1935, the percentage of cases without any dissenting opinions was always over 80 percent. $^{16}$

In fact, 1937 is familiarly thought to be the year that those debates came to an end, with a famous retreat by the Court. ${ }^{17}$ But between 1932 and 1937, when the conflict between the Roosevelt Administration and the Court was at its height, the rate of unanimous decisions was quite high, and saw a reduction only in 1937 itself, when significant doctrinal changes split the Court:

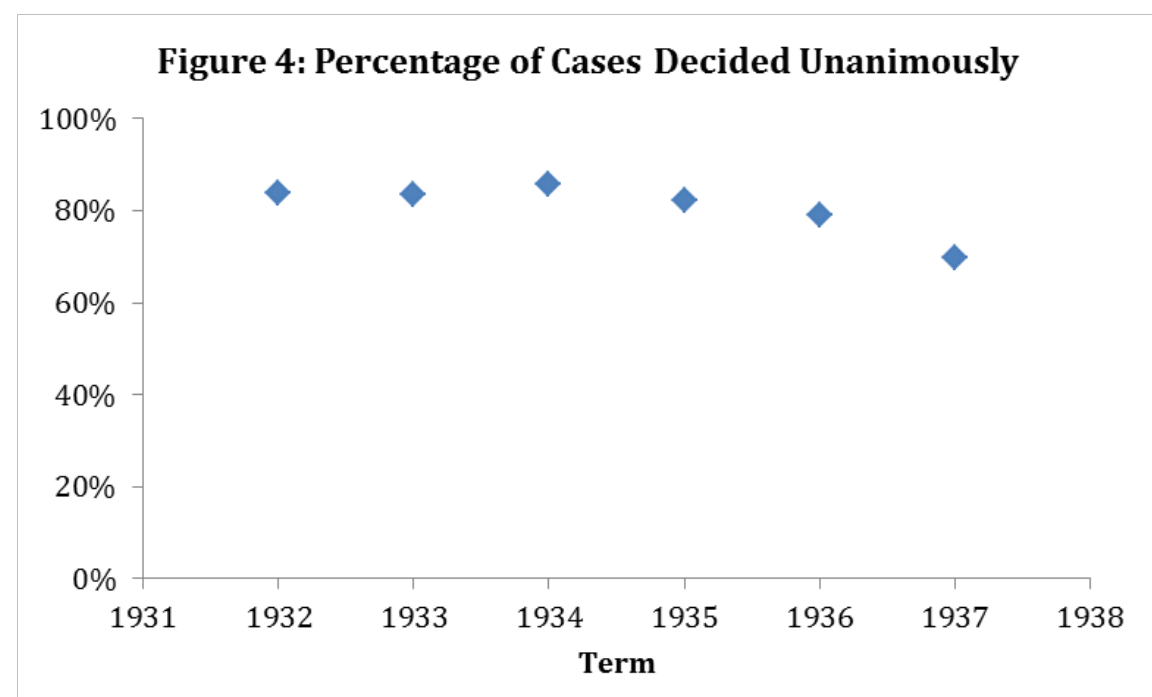

In 1937 and the years immediately following, Roosevelt was able to repopulate the Court with justices of his own choosing. ${ }^{18}$ And in those years, the Court is not known for having been divided by historically important doctrinal disagreements. How puzzling, then, that consensus would break down within that repopulated Court and in a relatively quiet period. To make progress on that puzzle, it is important to distinguish between an actual consensus on the one hand and a norm of consensus on the other. ${ }^{19}$ With an actual consensus, the justices agree with one

\footnotetext{
${ }^{15}$ This article defines decisions to be "unanimous" if they are decided by a 9-0 (or 8-0) vote. This definition includes decisions that contain concurrences in the judgment, which are not unanimous in the strictest sense. The broader definition is used here on the ground that if no one dissents from the judgment, the justices can be taken to be in relevant accord.

${ }^{16}$ Lee Epstein, JefFrey A. Segal, Harold J. Spaeth, \& Thomas G. Walker, The Supreme COURT COMPENDIUM: DATA, DECISIONS, AND DEVELOPMENTS, $5^{\text {th }}$ Ed. (2012), Table 3-2.

${ }^{17}$ See West Coast Hotel v. Parrish, 300 U.S. 379 (1937).

${ }^{18}$ Roosevelt nominated Hugo Black in 1937, Stanley Reed in 1938, Felix Frankfurter and William O. Douglas in 1939, Frank Murphy in 1940, and Harlan Fiske Stone, James Byrnes, and Robert H. Jackson on the same day in 1941. After Justice Byrnes resigned in order to lead the Office of Economic Stabilization, Roosevelt nominated Wiley Blount Rutledge in 1943.

${ }^{19}$ For valuable discussion from different perspectives, see Adrian Vermeule, Parliament of the Experts, 58 Duke L.J. 2231, 2254 (2009) ("expert panels sometimes gin up a consensus that does not actually exist"); Philippe Urfalino, Apparent Consensus and Voting: Two Models of
} 
another; they do not need any kind of norm to reach complete or near-unanimity. With a norm of consensus, patterns of complete or near-unanimity will emerge even thought the justices actually disagree. Because of the norm, that disagreement is not disclosed publicly. In any period, it might be exceedingly difficult to know whether high levels of public agreement reflect actual consensus or a norm of consensus. ${ }^{20}$ As we will see, the historic patterns seem to have a great deal to do with a sudden decline of the norm of consensus, and much less with an increase in actual disagreement.

\section{A. The Era of Consensus: 1800-1941}

1. The basic picture. From 1801 through 1836, the strong majority of terms had dissents in fewer than five percent of cases, and the average rate of dissents was 5.7 percent. ${ }^{21}$ In every year in that period, fewer than twenty percent of cases had even a single dissent.22 From 1837 to 1940, the overall dissent rate was 8.5 percent, and the dissent rate exceeded twenty percent during only seven terms $(1837,1845$, $1849,1852,1853,1854$, and 1938). ${ }^{23}$ From 1801 through 1940, the total dissent rate was 8.4 percent, and the median term had a dissent rate of 7.9 percent. ${ }^{24}$

If we look at concurrences, we will see a similar pattern. From 1801 through 1940, the overall percentage of cases with at least one concurring opinion was 1.7 percent, and the median term had a rate of 1.4 percent. $^{25}$ Remarkably, there was no term in which the rate of concurrences was as high as fifteen percent, and the concurrence rate exceeded ten percent during only five terms $(1805,1837,1842$, $1847,1856) .{ }^{26}$ In fact thirty-six years had no concurrences at all, and in seventy-two years (more than half the total), the number of dissents was one or fewer. ${ }^{27}$

Splits of 5-4 or 4-3 were also exceedingly rare. By 1940, the rate of such splits had exceeded ten percent only once (1810), and it exceeded five percent only ten times. ${ }^{28}$ By contrast, the percentage of unanimous cases was quite high - in most years at least 80 percent. ${ }^{29}$ Overall, the percentage of unanimous decisions was around 90 percent, and it might have been higher. ${ }^{30}$

Collective Decision-Making (2007), available at http://www.academia.edu/4277481/Apparent_Consensus_and_Vote

${ }^{20}$ For an illuminating and successful effort, showing the importance of the norm, see Lee Epstein et al., The Norms of Consensus on the U.S. Supreme Court, 45 Am J Polit Sci 362 (2001).

${ }^{21}$ Epstein et al., supra note, Table 3-2.

${ }^{22} \mathrm{Id}$.

${ }^{23} \mathrm{Id}$.

${ }^{24} \mathrm{Id}$.

${ }^{25}$ Id., Table 3-3.

${ }^{26} \mathrm{Id}$.

${ }^{27} \mathrm{Id}$.

${ }^{28}$ Id., Table 3-4.

${ }^{29}$ Id., Table 3-1

${ }^{30}$ Corley et al., Revisiting, supra note, at 22. 
2. A closer look. Here is a graphical presentation of the rates of dissents, concurrences, and one-vote margin from 1801 to 1940:

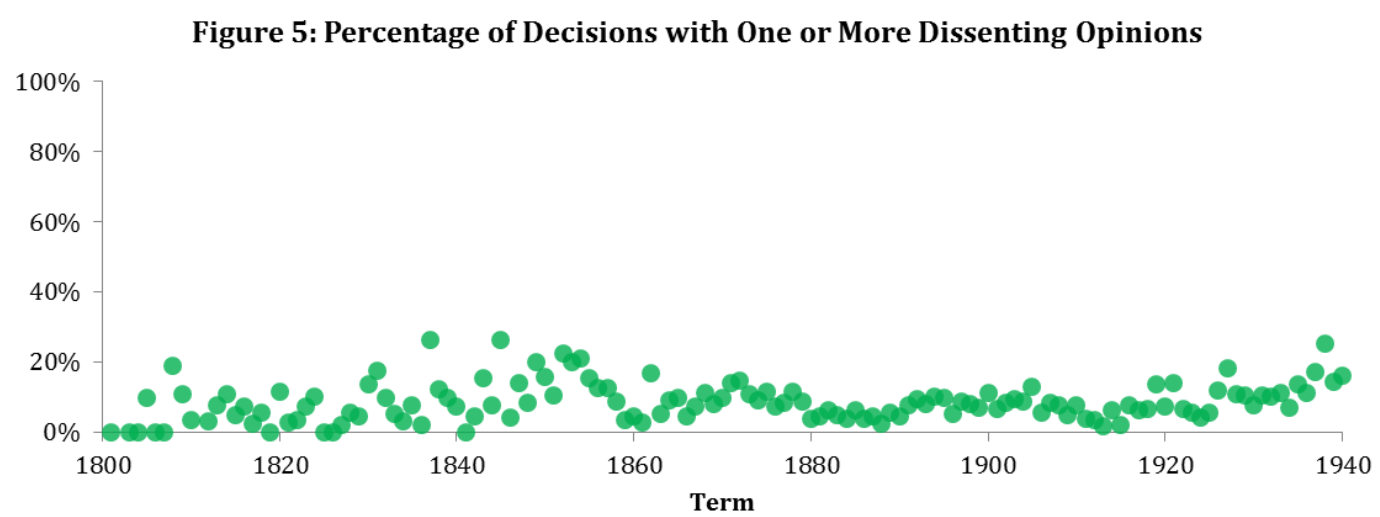

Figure 6: Percentage of Decisions with One or More Concurring Opinions

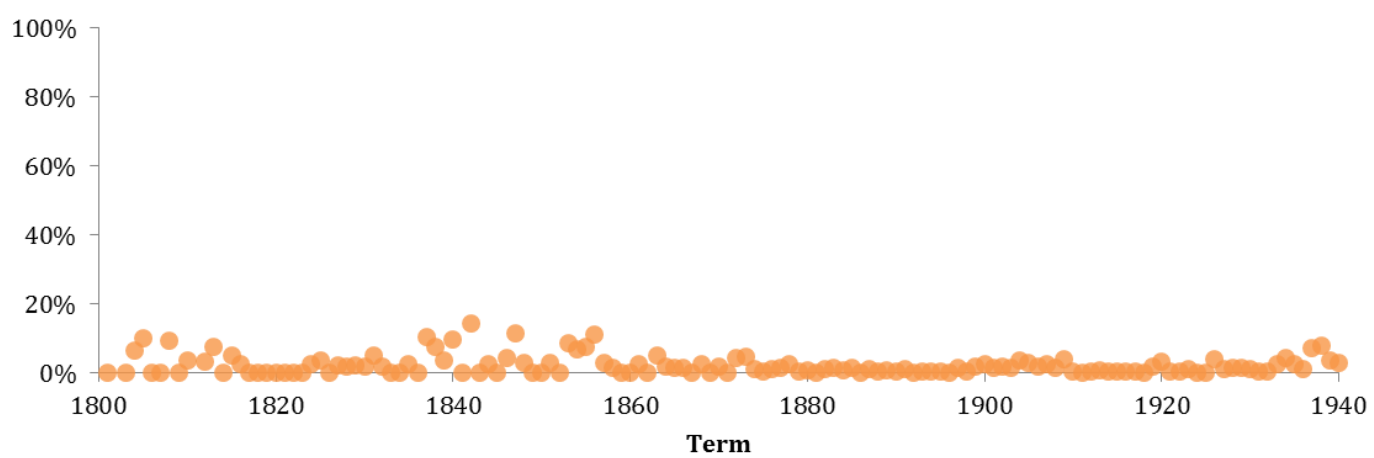

Figure 7: Percentage of Cases Decided by One-Vote Margin

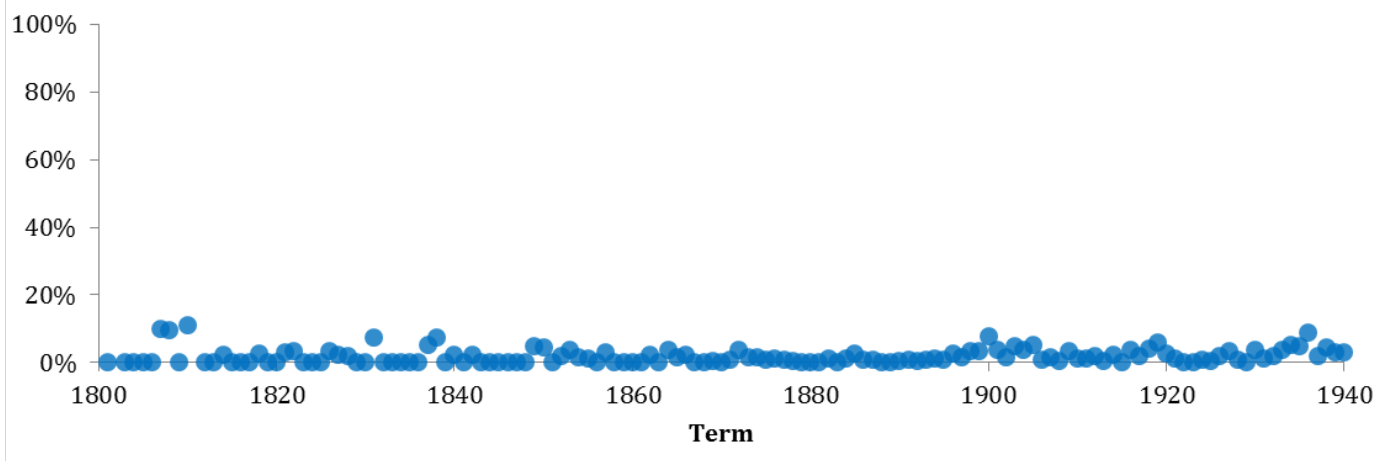

Here is a division of the patterns across relevant Chief Justices: 
Figure 8: Percentage of Decisions with One or More Dissenting Opinions

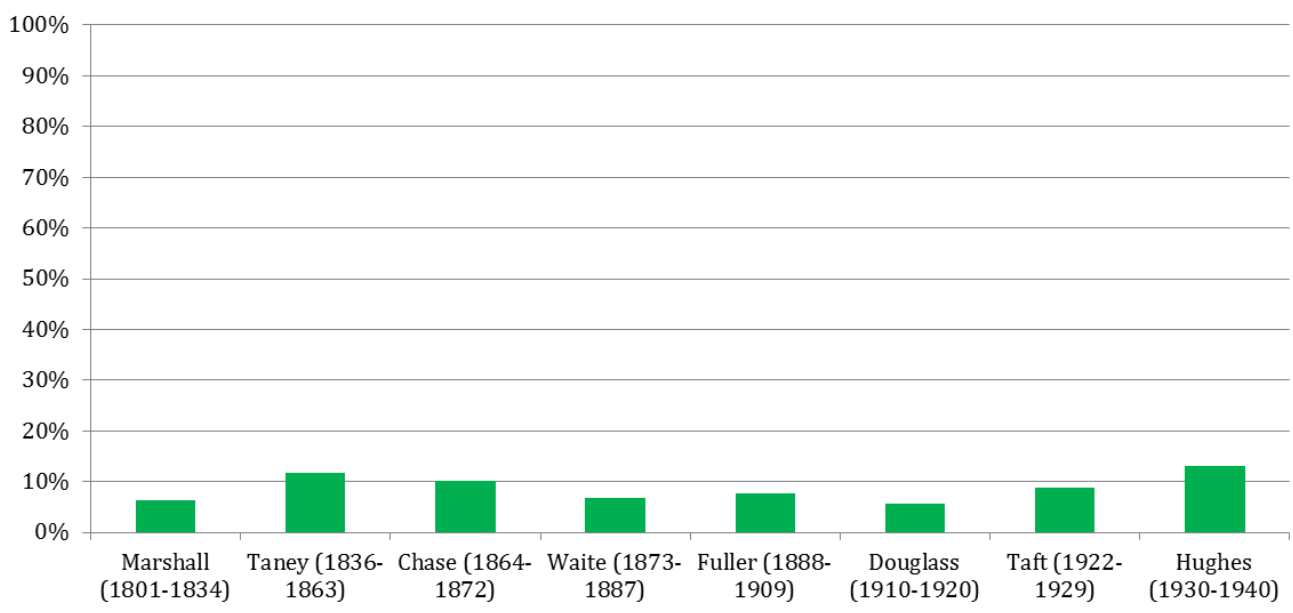

Figure 9: Percentage of Decisions with One or more Concurring Opinions

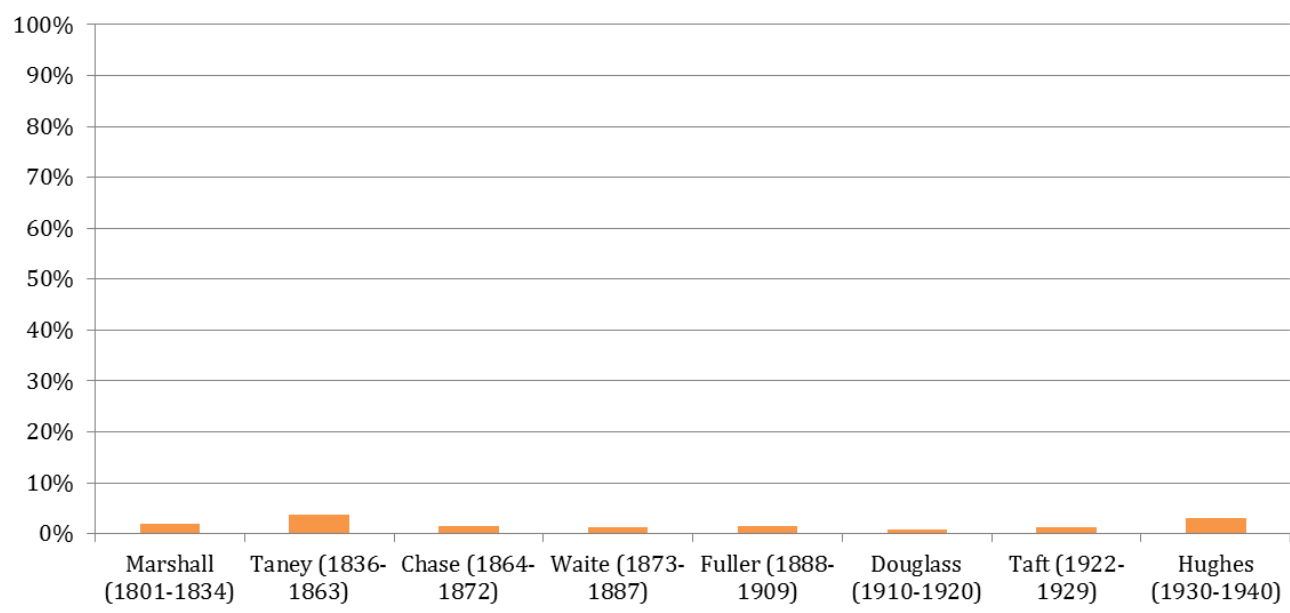

Figure 10: Percentage of Cases Decided by One-Vote Margin

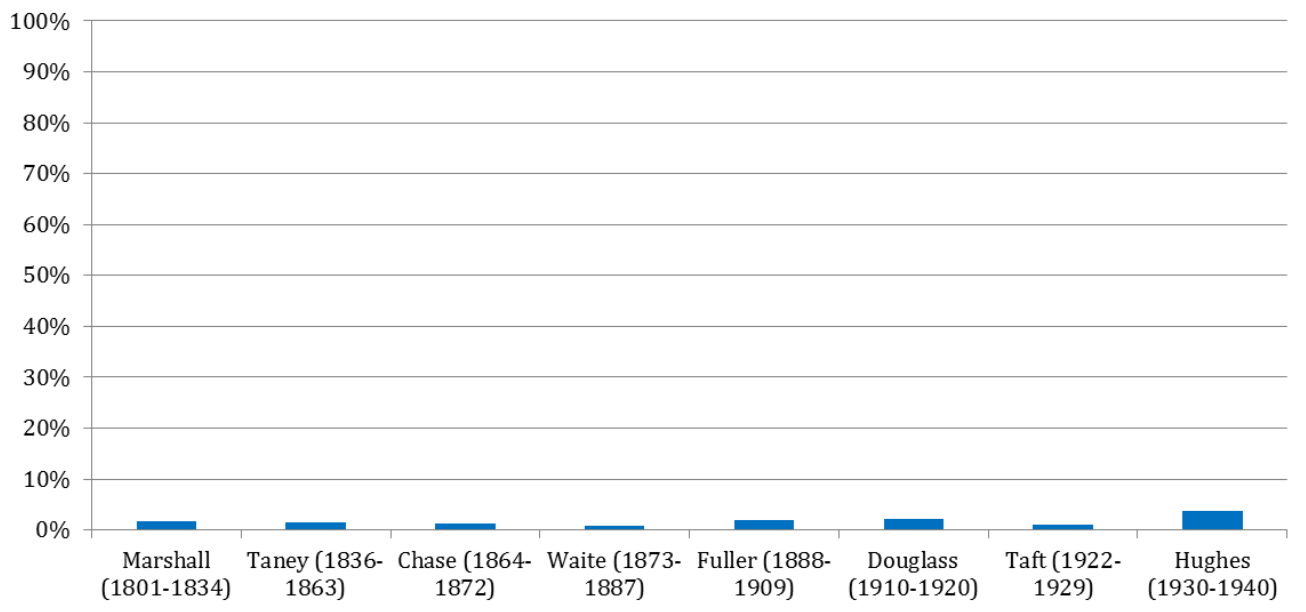

An obvious question is whether we can find statistically significant changes in all three trends across particular Chief Justices. In general, the answer is that we 
cannot. ${ }^{31}$ The graph does show some variations, to be sure. If we look carefully by Chief Justice, we can see an increase in dissents under Chief Justice Hughes, with a 13 percent rate compared by 10 percent under Taft and 6 percent under White. But differences of this relatively small magnitude are consistent with the expected variation of the data, and hence the patterns were not substantially different throughout this lengthy period.

Of course this conclusion speaks of aggregate cases, and not of particular disputes, where dissents can be found, and where disagreements were occasionally intense. The Court was famously divided in some of the great cases in American law, including Dred Scott v. Sanford, ${ }^{32}$ Lochner v. New York, ${ }^{33}$ Whitney v. California, ${ }^{34}$ Adkins v. Children's Hospital. ${ }^{35}$ In this light, we might describe the prevailing norm of consensus as suggesting that members of the Court should not express disagreement unless they were justified in doing so in light of the intensity of their disagreement and the magnitude of the stakes. As we shall see, this formulation seems to capture an understanding established under Chief Justice John Marshall.

\section{The Era of Independent Law Offices: 1941-Present}

1. The basic picture. From 1941 to the present, the picture is altogether different. In 1941, the rate of cases with dissenting opinions jumped to 29 percent, and then to 43 percent in 1942, and to 52 percent in $1943 .{ }^{36}$ From that point, it has fallen below 50 percent in only four years $\left(1996,1997,2005\right.$, and 2013). ${ }^{37}$ The overall rate of dissents is 60.5 percent, and in the median term, the rate was 60.7 percent. ${ }^{38}$

The rate of concurrences grew to 11 percent in 1941 and then to 16 percent in $1942 .{ }^{39}$ From that point, it has never fallen below 10 percent, and indeed it has been below 20 percent in only two years (1943 and 1944). ${ }^{40}$ The overall rate of concurrences is 37 percent, and in the median term, it is 38 percent. ${ }^{41}$

\footnotetext{
${ }^{31}$ Based on application of the Mann-Whitney test, with significance at a p-value $<0.01$ (to account for multiple hypothesis testing), the only significant changes between consecutive chief justices were the increase in the rate of dissenting opinions from Marshall to Taney (Figure 8) and the increase in the rate of cases decided by a one-vote margin from Taft to Hughes (Figure 10). See the Appendix for more detailed analysis.

${ }^{32}$ Dred Scott v. Sandford, 60 U.S. 393 (1857) (decided 7-2, with 6 concurring opinions and two dissenting opinions).

${ }^{33}$ Lochner v. New York, 198 U.S. 45 (1905) (decided 5-4, with 2 dissenting opinions).

${ }^{34}$ Whitney v. California, 274 U.S. 357 (1927) (decided 7-1, with 1 concurring opinion).

${ }^{35}$ Adkins v. Children's Hospital, 261 U.S. 525 (1923) (decided 5-3, with 2 dissenting opinions).

${ }^{36}$ Epstein et al., supra note, Table 3-2.

${ }^{37}$ Id.

${ }^{38} \mathrm{Id}$.

${ }^{39} \overline{\text { Id., }}$ Table 3-3.

${ }^{40} \mathrm{Id}$.

${ }^{41}$ Id.
} 
The percentage of cases decided by one vote jumped to 9.9 percent in 1941, and from that time, it has fallen below 10 percent in just twelve years. ${ }^{42}$ The overall percentage of 5-4 decisions is 16.6 percent, and in the median year, it is $\mathbf{1 7 . 9}$ percent. ${ }^{43}$

The percentage of unanimous decisions fell to 61 percent in 1941, to 49 percent in 1942, and to 38.5 percent in 1943. From that point, it has exceeded 50 percent only four times $(1996,1997,2005$, and 2013), and it has fallen below 40 percent in most years (40 out of 70 ). ${ }^{44}$

2. A closer look. The large shift unquestionably occurred under Chief Justice Stone. Under Hughes, the rate of dissent was 13 percent; it jumped to 45 percent under Stone. Under Hughes, the rate of concurrences was 3 percent; it jumped to 17 percent under Stone. Under Hughes, just 4 percent of cases were decided by one vote; that figure jumped to 11 percent under Stone. ${ }^{45}$ In fact the rate of expressed disagreement increased during the 1940s and early 1950s, with an all-time record of 52 percent in 1943, exceeded by 60 percent in 1946, and then again by 80 percent in 1952.46

Here is a graphical presentation of the rates of dissents, concurrences, and one-vote margins between 1941 and 2013:

\footnotetext{
${ }^{42}$ Id., Table 3-4.

${ }^{43}$ Id., Table 3-4.

${ }_{44}^{4} \mathrm{Id}$.

45 See Corley et al., supra note, at 24.

${ }^{46} \mathrm{Id}$.
} 


\section{Figure 11: Percentage of Decisions with One or More Dissenting Opinions}

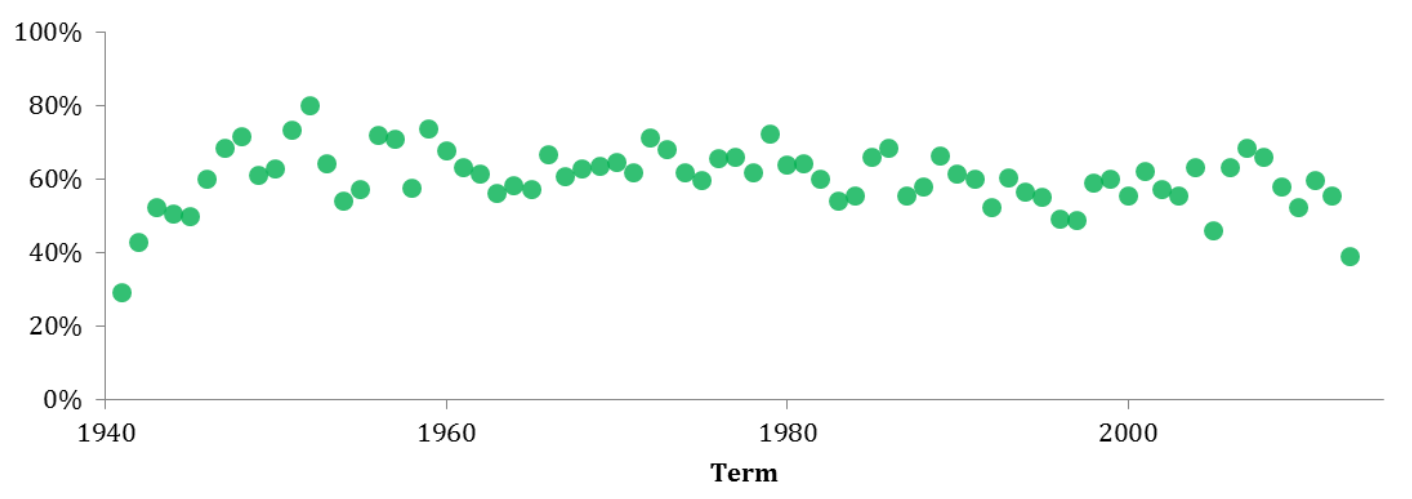

Figure 12: Percentage of Decisions with One or More Concurring Opinions

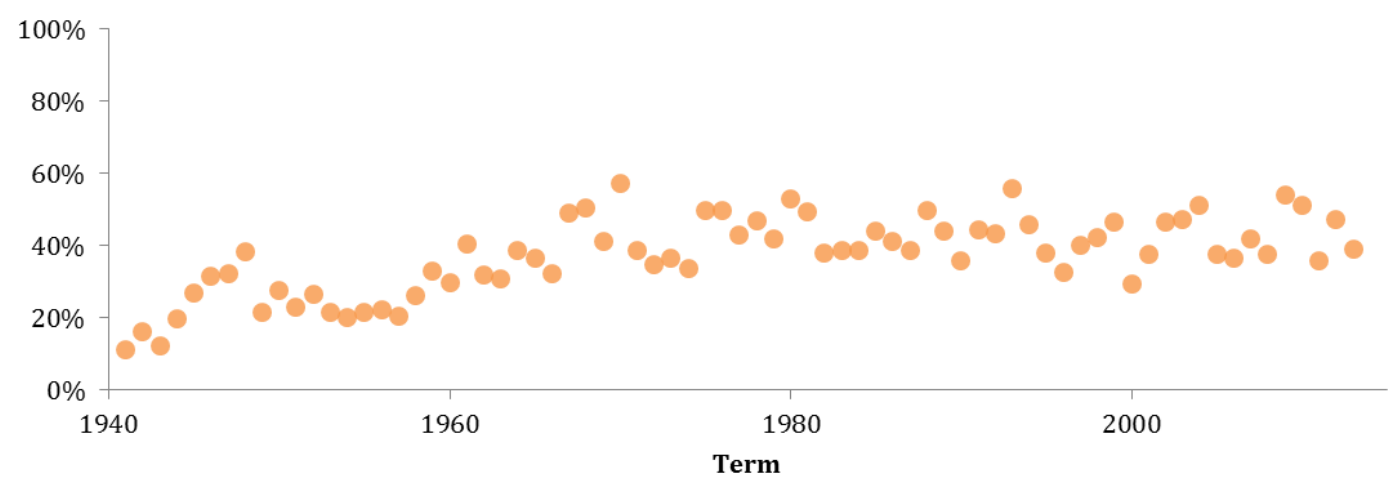

Figure 13: Percentage of Cases Decided by One-Vote Margin

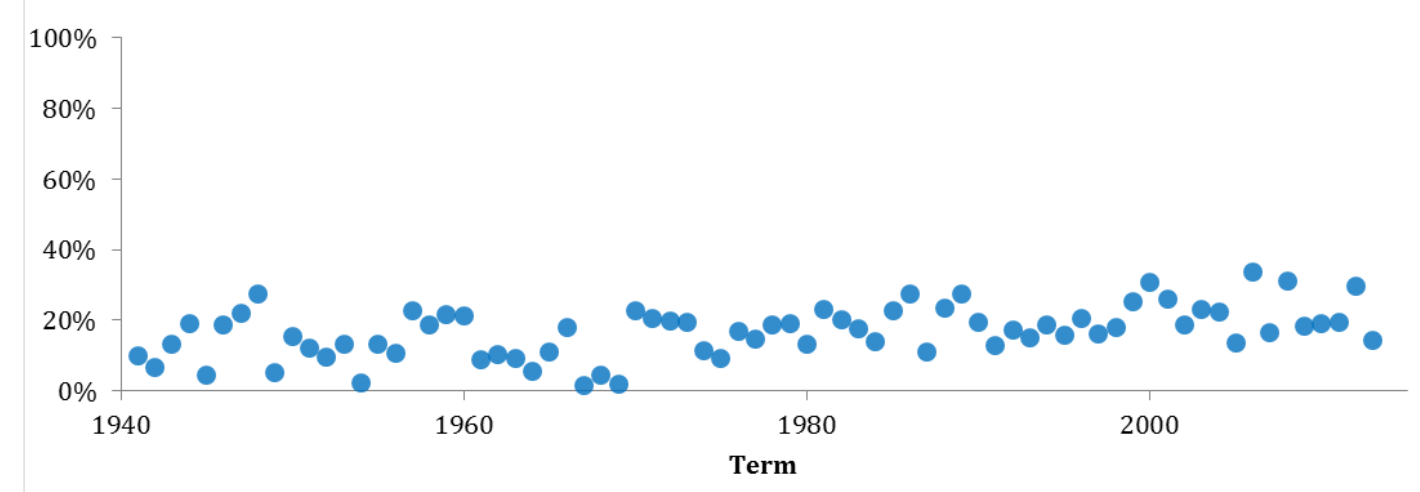


Here is a division of the patterns across relevant Chief Justices:

Figure 14: Percentage of Decisions with One or More Dissenting Opinions

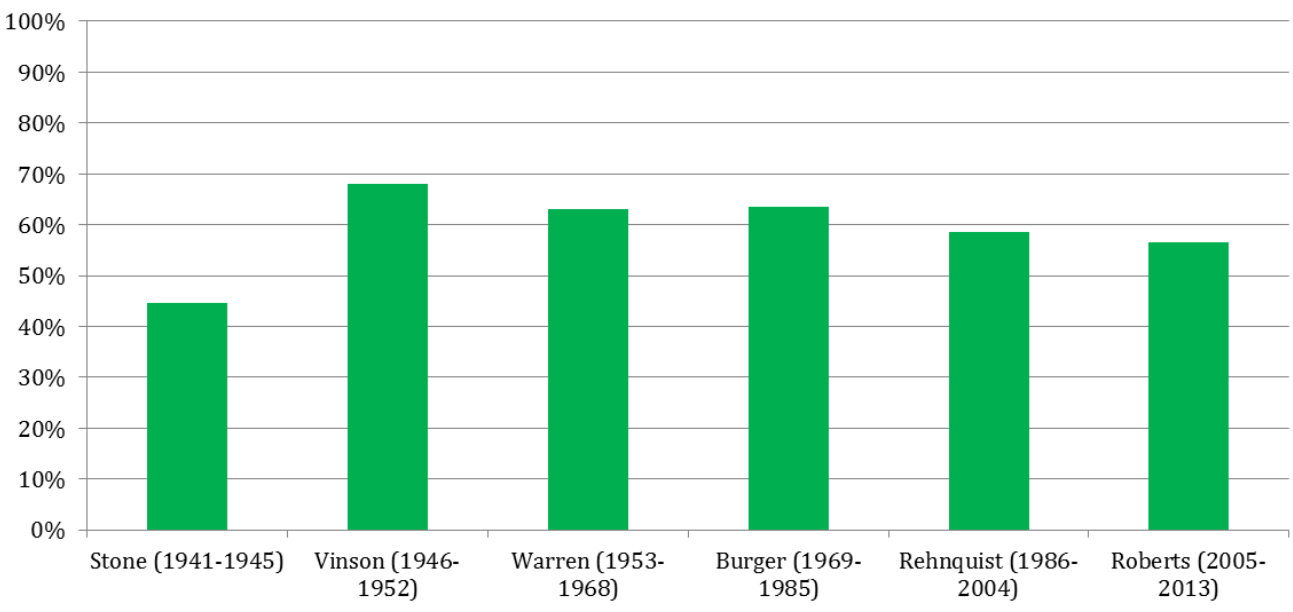

Figure 15: Percentage of Decisions with One or More Concurring Opinions

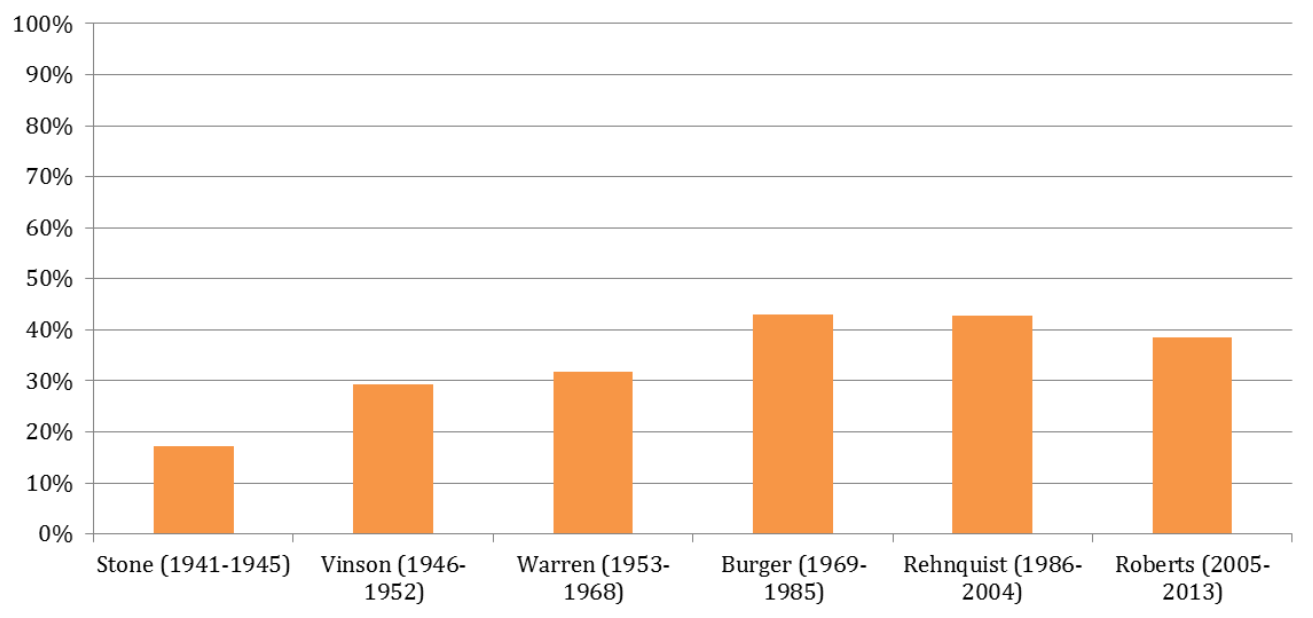

Figure 16: Percentage of Cases Decided by One-Vote Margin

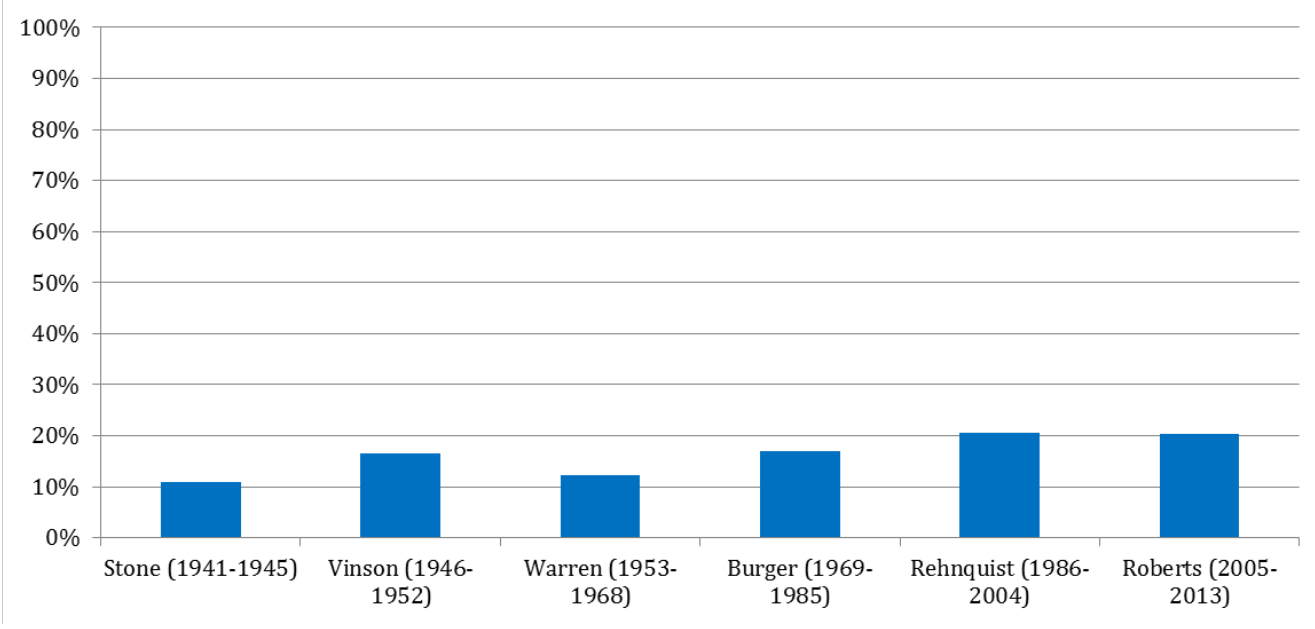


Here again, an obvious question is whether we can find statistically significant changes between any Chief Justice and his replacement. For the most part, the changes in the height of the bars are not significant. ${ }^{47}$ From Figures $11-13$, we can also see that there may be gradual, background trends of decrease (in dissenting opinion rates) or increase (in concurring opinion rates) operating on a time scale of multiple decades, but there has not been any abrupt or large-scale change since 1941 .

\section{E. What Happened in 2013? A Note}

The 2013 Term has been widely seen to be an outlier. ${ }^{48}$ In that Term, the percentage of 5-4 divisions was relatively low - 14 percent, the lowest since 2005 . At the same time, this number was well within the post-1941 range (with twentyfive years since that time having lower rates of 5-4 decisions). The percentage of cases with concurrences, 39 percent, was also well within the expected range, in fact quite close to the average since 1941 (37 percent). But there was a dramatic increase in unanimous opinions (at 62 percent $^{49}$ ) and an equally decrease in the rate of dissenting opinions (at 39 percent). As a result, 2013 saw the highest rate of unanimous opinions and the lowest rate of dissenting opinions since 1940, and both changes represent statistically significant movements from the decades-long pattern. ${ }^{50}$

What accounts for the increase in unanimity? The most obvious possibility, and the most intriguing one, is that Chief Justice Roberts was finally able to succeed in carrying out the task he set for himself in 2006. Perhaps he was able to convince his colleagues to return to some version of the pre-1941 norm. But for several reasons, it would be a premature to see the 2013 Term data as reflecting anything like such a return. First, we have just seen that the rates of both dissents and concurrences were within historical ranges; on these counts, there was no major dip. Second, some of the apparently unanimous decisions actually reflect a high degree of internal disagreement. In the Canning case, for example, involving recess appointments, the Court was unanimous on the judgment, but divided 5-4 on the

\footnotetext{
${ }^{47}$ Based on application of the Mann-Whitney test, with significance at a p-value $<0.01$ (to account for multiple hypothesis testing), the only significant changes are the increase in percentage of decisions with concurring opinions from Warren to Burger (Figure 15) and the decrease in dissents from Burger to Rehnquist (Figure 14). Again, in no case was there a significant change across all three trends, as there was between Hughes and Stone. For details, see the Appendix.

${ }^{48}$ See, e.g., Adam Liptak, Compromise at the Supreme Court Veils Its Rifts, N.Y. Times, July 2, 2014, at A1; Sean Lengell, Supreme Court not as unified as it looks, Washington Examiner, July $2,2014, \mathrm{http}: / /$ washingtonexaminer.com/supreme-court-not-as-unified-as-itlooks/article/2550448.

${ }^{49}$ Different numbers have been reported, due to different customs for counting per curiam opinions. This number was calculated in the same way as the earlier data used here.

${ }^{50}$ See Appendix, infra, for the method of calculating this difference.
} 
most fundamental questions. ${ }^{51}$ Third, the Court has not, under Chief Justice Roberts, shown any overall reduction in the levels of disagreement exemplified by the post1941 patterns. ${ }^{52}$ It is also true that the numbers might be an inadequate way of capturing the level of internal disagreement if the Court is split 5-4 on the most important questions - as is plausibly true for the 2013 term. ${ }^{53}$ For these reasons, it is far too early to think that there was, in 2013, a sufficient signal to justify any conclusions about a new trend.

\section{Explanations}

What accounts for these patterns? In this Section, I discuss, in sequence, the norm of consensus, the dramatic change in 1941,54 and the longstanding persistence of the patterns initially established in that year. The principal account is one of path dependence. Without Chief Justice Marshall, the norm of consensus might never have developed at all. And without Chief Justice Harlan Fiske Stone, it is imaginable that it would continued much longer, conceivably even to the present day. But as we will see, existing norms, and in that sense institutional culture, is also important. Once a path has been established, norms and culture might be established as well, and it might not be easy for anyone, including a chief justice, to alter it. 55

\section{A. The Norm of Consensus}

1. A little history. It is well-known that Chief Justice John Marshall worked exceedingly hard, and quite successfully, to produce a norm in favor of unanimity. ${ }^{56}$ Production of that norm was hardly foreordained. With another chief justice, the Court might have taken a radically different course.

In its initial years under Chief Justice John Jay, the Court decided cases seriatim, with opinions published by reverse seniority, so that the Chief Justice delivered his opinion last. Often the last opinion was followed by a brief paragraph announcing the outcome, headed with three words: "By the Court."57 Chief Justice Jay was succeeded by Oliver Ellsworth, who maintained a great deal of continuity with this practice, but who also reduced the tribunal's reliance on seriatim opinions and

${ }^{51}$ NLRB v. Canning, US (2014).

${ }^{52}$ See supra.

${ }^{53}$ See, e.g., Burwell v. Hobby Lobby Stores, U.S. (2014); McCutcheon v. FCC, U.S. (2014).

${ }^{54}$ Walker et al., remains the most illuminating discussion, and I have been much influenced by it here.

${ }_{56}^{55}$ For relevant discussion, see Ulmann-Margalit, Revision of Norms, supra note.

${ }^{56}$ See, e.g., Ginsburg, supra note, at 2-3; David M. O'Brien, Institutional Norms and Supreme Court Opinions: On Reconsidering the Rise of Individual Opinions, in SUPREME COURT DECISION-MAKING: NEW INSTITUTIONALIST APPROACHES 91, $92-93$ (Howard Gillman \& Cornell W. Clayton, eds., 1999); Aaron J. Lay et al., The Mysterious Persistence of NonConsensual Norms on the U.S. Supreme Court, 49 Tulsa L Rev 99 (2013).

${ }^{57}$ G. Edward White, The Internal Powers of the Chief Justice: The Nineteenth-Century Legacy, 154 U. PA. L. REV. 1463, 1466 (2006). 
increased use of opinions of the Court, announced by the Chief Justice. ${ }^{58}$ We do not know if Ellsworth thought that it was important to make this shift, or whether it was a simple matter of convenience. ${ }^{59}$

Apparently focusing on the need for institutional legitimacy and prestige, Marshall went much further. He wholly rejected the seriatim method of rendering decisions, and he worked successfully to promote unanimity within the Court. ${ }^{60}$ Under his leadership, the preexisting "By the Court" paragraph was transformed into the modern "Opinion of the Court." 61 Marshall strongly discouraged dissenting opinions, and he himself wrote a large number of the Court's opinions, even if he was not in agreement with the ruling, thus fortifying the idea of public unanimity. ${ }^{62}$ Under Marshall's leadership, seriatim opinions disappeared. As Marshall explained, "The course of every tribunal must necessarily be, that the opinion which is delivered as the opinion of the court, is previously submitted to the judges; and, if any of the reasoning be disapproved, it must be so modified as to receive the approbation of all before it can be delivered as the opinion of all." 63

Importantly, the "Opinions of the Court" were ambiguous with respect to the question whether they reflected the views of all of the justices or only a majority. ${ }^{64}$ The public could not know the answer to that question, which mattered, because ambiguity worked to ensure that if a particular judge did not write separately, his own views would not be revealed. This practice reduced the pressure to write separately. It was clear that some justices, some of the time, silently acquiesced in the Court's rulings, and indeed, several published opinions explicitly acknowledged this norm. In one of his rare dissents, Marshall began with a disclaimer: "I should now, as is my custom, when I have the misfortune to differ from this Court, acquiesce silently in its opinion." 65 So did Joseph Story: "Had this been an ordinary case I should have contented myself with silence; but ... I have thought it not unfit to pronounce my own opinion ...." 66 So did Bushrod Washington: "It has never been my habit to deliver dissenting opinions where it has been my misfortune to differ from those which have been pronounced by a majority of this Court."67

\footnotetext{
${ }^{58}$ Id. at 1467.

${ }^{59}$ Id. at 1469.

${ }^{60}$ See Walker et al., supra note, at 362; O’Brien, supra note, at 92; M. Todd Henderson, From Seriatim to Consensus and Back Again: A Theory of Dissent 23 (John M. Olin Program in Law and Economics Working Paper No. 363, 2007).

${ }^{61}$ White, supra note, at 1470 .

${ }^{62}$ O'Brien, supra note, at 92-93.

${ }^{63}$ John Marshall, A Friend of the Union, quoted in Jean Edward Smith, John Marshall: Definer of A Nation 282 (1998). On the relationship between Marshall's work on behalf of unanimity and the Court's limited prestige, see id. at 282-87.

${ }^{64}$ White, supra note, at 1470.

${ }^{65}$ Bank of the United States v. Dandridge, 25 U.S. (12 Wheat.) 64, 90 (1827) (Marshall, C.J., dissenting), quoted in White, supra note, at $1471 \mathrm{n} .17$.

${ }^{66}$ The Nereide, 13 U.S. (9 Cranch) 388, 455 (1815) (Story, J., dissenting), quoted in id.

${ }^{67}$ Mason v. Haile, 25 U.S. (12 Wheat.) 370, 379 (1827) (Washington, J., dissenting), quoted in id.
} 
These statements reveal that some of the time, a norm of consensus was very much in force and accounted for the absence of a public dissent. Notwithstanding their silence, the justices did not actually agree. Because of his effectiveness in promoting that consensus, Marshall can be seen as a norm entrepreneur, one who was able to succeed in part because of his multiple skills ${ }^{68}$ and in part because of his distinctive role as chief justice. With respect to consensus and dissent, Marshall was undoubtedly the most important norm entrepreneur in the Court's history - with the possible exception of Harlan Fiske Stone, who was in crucial respects the antiMarshall (as we shall see).

The practice of silent acquiescence was not without prominent critics. In a letter to his appointee William Johnson, Thomas Jefferson complained that with that practice, no one could possibly know "what opinion any individual member gave in any case, nor even that he who delivers the opinion, concurred in it himself." 69 Jefferson objected that "[t]he practice is certainly convenient for the lazy, the modest \& the incompetent," because it "saves them the trouble of developing their opinion methodically and even of making up an opinion at all."70

In his illuminating response, Johnson explained that after his own appointment, a case arose "In which I differed from my brethren, and I thought it a thing of course to deliver my opinion. But, during the rest of the session I heard nothing but lectures on the indecency of judges cutting at each other, and the loss of reputation which the Virginia appellate court had sustained by pursuing such a course. At length I found that I must either submit to circumstances or become such a cypher in our consultations as to effect no good at all."71 Interestingly, and in a way that seemed to support Jefferson's emphasis on convenience "for the lazy, the modest \& the incompetent," Johnson went on to suggest that the "real cause" of silent acquiescence was a desire to protect the justices who lacked either the will or the ability to write separately. ${ }^{72}$ For justices who lacked the capacity to explain their views, silent acquiescence had significant advantages, because it relieved them of the obligation to say what they thought. ${ }^{73}$

\footnotetext{
${ }^{68}$ For one treatment, see Smith, supra note.

${ }^{69}$ Letter from Thomas Jefferson to William Johnson (Oct. 27, 1822), in 10 The Writings of Thomas Jefferson, 1816-1826, at 225, quoted in White, supra note, at 1473.

${ }^{70} \mathrm{Id}$.

${ }^{71}$ Letter from William Johnson to Thomas Jefferson (Dec. 10, 1822), quoted in Donald G. Morgan, Justice William Johnson: The First Dissenter: The Career and Constitutional Philosophy of a Jeffersonian Judge 181-82 (1954), quoted in White, supra note, at 1473.

${ }^{72} \mathrm{Id}$.

${ }^{73}$ This point suggests the possibility that the norm of consensus solved a collective action problem, at least for some of the justices. See Ullmann-Margalit, supra note. With that norm in place, they could remain silent in circumstances in which it was in their interest to do so. See the discussion of "effort aversion" in Lee Epstein et al., The Behavior of Federal Judges 7, 12 (2013).
} 
Marshall served as Chief Justice for thirty-four years, and by the time he left the bench, the norm of consensus had become well-entrenched. For over a century after his departure, silent acquiescence persisted. ${ }^{74}$ Until 1941, all of Marshall's successors appeared to favor the consensus norm. ${ }^{75}$ For example, Chief Justice Chase said "that except in very important causes [filing] dissents [was] inexpedient."76 Chief Justice Taft strongly believed in the maxim, "no dissent unless absolutely necessary." He once explained: "I don't approve of dissents generally, for I think in many cases where I differ from the majority, it is more important to stand by the Court and give its judgment weight than merely to record my individual dissent where it is better to have the law certain than to have it settled either way." ${ }^{77}$ He wrote to Stone personally, "I am quite anxious, as I am sure we are all, that the continuity and weight of our opinions on important questions of law should not be broken any more than we can help by dissents.... I hope you will look into the matter with care, because 5 to 4 decisions of the Court, while they must sometimes occur, don't help the weight of its judgment."78 Chief Justice Hughes agreed with Taft. ${ }^{79}$ Justice Pierce Butler captured the longstanding view: "I shall in silence acquiesce. Dissents seldom aid in the right development or statement of the law. They often do harm. For myself I say: 'lead us not into temptation.'”80

Justice Holmes and Justice Brandeis are sometimes treated as history's "great dissenters," but their behavior did not depart dramatically from the standards of the period, with an average of 2.48 and 4.4 dissents per term. ${ }^{81}$ These rates are a strikingly low compared to (for example) the rates of 10.9 for Felix Frankfurter, 14.29 for William 0. Douglas, 5.94 for William Brennan, and even 5.5 for Louis Powell, known as a centrist and hardly a dissenter. ${ }^{82}$

\section{B. What Happened in 1941?}

\footnotetext{
${ }^{74}$ White, supra note; Walker et al., supra note.

${ }^{75}$ From the contemporary perspective, it is a genuine oddity that the justices sometimes did not see the actual opinion before it was published - a point suggesting that the reasoning reflected the views of only the author. White, supra note, at 1482.

${ }^{76} \mathrm{O}$ 'Brien, supra note, at 93.

${ }^{77}$ Quoted in O'Brien, supra note, at 93.

${ }^{78}$ Quoted in Corley et al., supra note, at 31.

${ }^{79}$ Walker et al., supra note, at 382.

${ }^{80}$ Quoted in HENRY J. ABRAHAM, ThE JUdiCiAL Process 224(5th ed. 1986), Walker et al., supra note at 381 .

${ }^{81}$ Albert P. Blaustein \& Roy M. MERSKy, The First One Hundred Justices: Statistical STUDiES ON THE SUPREME COURT OF THE UNITED STATES 148 (1978).

${ }^{82}$ Id. at 148-49. For relevant discussion by Justice Brennan, see William Brennan, In Defense of Dissents, 37 Hastings L. J. 427 (1986); for Justice Ginsburg's perspective, see Ruth Bader Ginsburg, The Role of Dissenting Opinions, 95 Minn L Rev 1 (1995)
} 
It is clear that in 1941, the norm in favor of consensus collapsed, and it did so with spectacular speed. What happened? There are many possible explanations ${ }^{83}$; I discuss them in decreasing order of plausibility.

\section{Chief Justice Stone}

In 1941, Harlan Fiske Stone was elevated to the position of Chief Justice. In the relevant respects, he was the anti-Marshall. In sharp contrast to his predecessors, Stone was generally uninterested in consensus, and he actually seemed to favor the transformation that occurred on his watch. He chafed under the control of Chief Justice Hughes and strenuously resisted the idea of silent acquiescence. ${ }^{84}$ As early as 1930, Justice James McReynolds implored Stone not to dissent: "If the Court is broken down, then there will be rejoicing in certain quarters. I cannot think the last 3 dissents which you have sent me will aid you, the law or the Court." 85 Stone's answer was revealing. He complained that if the majority "insists in putting our opinions which do not consider or deal with questions raised by the minority, it must, I think, be expected that the minority will give some expression to its views." 86

As Stone wrote in a candid passage, unambiguously separating himself from Marshall and his successors, "The right of dissent is an important one and has proved to be such in the history of the Supreme Court. I do not think it is the appropriate function of a Chief Justice to attempt to dissuade members of the Court from dissenting in individual cases." ${ }^{87}$ Indeed, Stone linked dissent with the development of sound principles, which, he contended, "are the ultimate resultant of the abrasive force of the clash of competing and sometimes conflicting ideas." ${ }^{88}$

His own behavior tracked his stated conviction. As Chief Justice, he dissented 13.5 percent of the time, a far higher rate than that of any of his predecessors, and a higher rate than that of his two immediate successors as well:

\footnotetext{
${ }^{83}$ Valuable discussions include Walker et al., supra note; O'Brien, supra note.

${ }^{84}$ Walker et al., supra note, at 383.

${ }^{85}$ Corley et al., supra note, at 30.

${ }^{86} \mathrm{Id}$.

${ }^{87}$ Quoted in Walker et al., supra note , at 379.

${ }^{88}$ Id.
} 
Table 1

\begin{tabular}{lccc}
\multicolumn{4}{c}{ DiSSENT BEHAVIOR OF ELEVEN CHIEF JUSTICES* } \\
\hline $\begin{array}{c}\text { Chief } \\
\text { Justice }\end{array}$ & $\begin{array}{c}\text { N of Chief } \\
\text { N of Cases }\end{array}$ & $\begin{array}{c}\text { Dissent } \\
\text { Justice Dissents }\end{array}$ & $\begin{array}{ccc}\text { Proportion } \\
{ }^{\mathrm{a}}\end{array}$ \\
\hline Marshall & 1187 & 7 & .0058 \\
Taney & 1708 & 38 & .0222 \\
Chase & 1109 & 33 & .0297 \\
Waite & 2642 & 45 & .0170 \\
Fuller & 4866 & 113 & .0232 \\
White & 2541 & 39 & .0153 \\
Taft & 1708 & 16 & .0093 \\
Hughes & 2050 & 46 & .0224 \\
Stone & 704 & 95 & .1349 \\
Vinson & 723 & 90 & .1244 \\
Warren & 1772 & 215 & .1213 \\
\hline
\end{tabular}

*Source: Ulmer (1986), p. 53.

${ }^{\text {a}}$ Number of Chief Justice dissents divided by number of cases.

source: Walker et al., 1988.

Chief Justice Stone did not merely welcome dissents and practice what he preached. He also helped initiated a large number of internal changes that were highly conducive to a breakdown of the previous norms. ${ }^{89}$ These included significantly longer discussions in conference, in which competing positions were offered and debated, and in which separate coalitions were developed. ${ }^{90}$ Under his leadership, the Court also abandoned its previous rule in favor of twenty-four deadlines for commenting on drafts - thus allowing for more extensive responses, which could easily be developed into concurrences and dissents. ${ }^{91}$ With these changes, the Court began to develop into separate law offices, which individual justices elaborating their own views, and feeling far freer to express those views in public. ${ }^{92}$

\section{New and independent-minded justices}

\footnotetext{
${ }^{89}$ Pamela C. Corley, Amy Steigerwalt, \& Artemus Ward, Revisiting the Roosevelt Court: The Critical Juncture from Consensus to Dissensus, 38 J. Sup. Ct. Hist. 22 (2013).

${ }^{90}$ Id. at $32-33$.

${ }^{91}$ Id. at 35-36.

${ }^{92}$ Walker et al., supra note, at 362 . The justices' greater reliance on law clerks, including their increasing number, is undoubtedly relevant to the rise of separate opinions, if only because it became easier for justices to produce them. A helpful discussion is Paul Baier, The Law Clerks: Profile of an Institution, 26 Vand. L. Rev. 1125 (1973). But with respect to the increase in internal division, law clerks are best understood as a second-order factor, and not a strong causal force.
} 
On the basis of these points, it would be possible to conclude that with respect to the transformation of 1941, "Chief Justice Stone did it." 93 But the conclusion is too simple. In the relevant period, the Court experienced extraordinarily rapid turnover. Roosevelt appointed Hugo Black in 1937, followed by Stanley Reed in 1938, Felix Frankfurter and William 0. Douglas in 1939, Frank Murphy in 1940, and James Byrnes and Robert Jackson in 1941, when Stone became Chief Justice. Between 1937 and 1941, the Court was a radically transformed tribunal, with only one holdover member in addition to Stone (Owen Roberts, appointed in 1930). As I have noted, the transformation deepens the puzzle. It might not have been anticipated that there would be a sudden outbreak of concurrences and dissents with effectively eight Roosevelt selections, sitting with Justice Roberts. Appointment by the same president should dampen disagreement, or so it might be thought. Justices with similar views might not be expected to reject a norm of consensus, and they might be expected to agree in fact, whatever the prevailing norm with respect to public expression of disagreement.

Indeed, it might well be questioned whether and when a Chief Justice is a necessary or sufficient condition for the transformation. If a norm in favor of consensus is well-entrenched, and if most of the justices are acculturated and committed to it, it might be doubted whether a new Chief Justice could significantly alter it. If, for example, Stone had been Chief Justice in 1891, 1901, 1911, 1921, or 1931 , a large-scale shift would probably not have occurred. The other members of the Court might well have resisted any effort to inaugurate such a shift. And if Hughes had been Chief Justice in 1941, it is at least worth wondering whether he would have been able to prevent at least some kind of change. In this light, we might consider another hypothesis, which is that the new justices were uninterested in maintaining the old norm, and hence that any Chief Justice would have had real difficulty in doing so. On a strong version of the "new justices" hypothesis, Chief Justice Stone was neither necessary nor sufficient for the shift. On the weak version of the same hypothesis, Chief Justice Stone was necessary, but he was not sufficient.

The key point here is that the new justices, above all Frankfurter, favored a more academic atmosphere, in which justices would develop competing views and ultimately feel free to express them. ${ }^{94}$ Consider Frankfurter's remarkable words, circulated to one of his colleagues: "Just because we agree in the result ... and because no immediately important public issue is involved by our different approaches in reaching the same legal result, it is at once interesting and profitable to discuss the underlying jurisprudential problem. And so I venture to make some observations on your opinion, I hope in the same spirit and for the same academic purpose as I would were I writing a piece as a professor in the Harvard Law

\footnotetext{
${ }^{93}$ This is a potential reading of Walker et al., supra, though their presentation has a great deal of subtlety.

${ }^{94}$ Walker et al., supra note, at 374.
} 
Review."95 In a Memorandum for the Conference, Frankfurter wrote that while "Unanimity is an appealing abstraction," it is also true that "a single Court statement on important constitutional issues and other aspects of public law is bound to smother differences that in the interests of candor and of the best interest of the Court ought to be express." 96

In terms of his desire for self-expression, Frankfurter may well have been an extreme case, certainly in the early 1940s, but Douglas had been a professor as well, and as the course of his career demonstrates, he was fully willing to speak on his own. Hugo Black was not so different, and Jackson of course had a unique voice, which he was hardly averse to using. Frankfurter, Douglas, Black, and Jackson also had strong personalities, and as recent members of the Court, they had not been fully socialized into a judicial culture that prized a norm of consensus. Because of their relative youth and inexperience, we might wonder whether they were likely to accept that norm lightly. At least once Stone essentially unleashed them, they were likely to break the norm down. We cannot say whether and to what extent they would have done so without Stone, or whether and to what extent a more directive Chief Justice, intent on preserving the longstanding norm, might have been able to succeed. But we might want to conclude that the combination was a perfect storm.

This is a tempting conclusion, but it does run into serious empirical objection. ${ }^{97}$ From 1937 to 1940, a number of the new justices sat on the Court, but they did not show significant levels of independent opinion-writing. ${ }^{98}$ Consider this table, showing the percentage of cases each term in which a justice wrote a dissenting opinion, of the new justices from 1937 to 1942:

Table 2: Dissent Rates of Associate Justices, Before and After Stone Became Chief Justice

\begin{tabular}{|c|c|c|c|c|c|c|}
\hline & \multicolumn{5}{|c|}{ Pre-Stone Terms } & \multicolumn{2}{c|}{ Stone Terms } \\
\hline Justice & $\mathbf{1 9 3 7}$ & $\mathbf{1 9 3 8}$ & $\mathbf{1 9 3 9}$ & $\mathbf{1 9 4 0}$ & $\mathbf{1 9 4 1}$ & $\mathbf{1 9 4 2}$ \\
\hline Black & $5.26 \%$ & $4.32 \%$ & $1.46 \%$ & $2.42 \%$ & $6.62 \%$ & $8.16 \%$ \\
\hline Reed & & $1.44 \%$ & $0.73 \%$ & $1.21 \%$ & $3.97 \%$ & $2.72 \%$ \\
\hline Douglas & & & $0 \%$ & $1.21 \%$ & $3.97 \%$ & $8.16 \%$ \\
\hline Murphy & & & $0.73 \%$ & $0.61 \%$ & $0.66 \%$ & $0.68 \%$ \\
\hline
\end{tabular}

\footnotetext{
${ }_{95}^{95}$ Quoted in Corley et al., supra note, at 40.

${ }_{97}^{96}$ Quoted in O'Brien, supra note, at 107-108.

${ }^{97}$ Walker et al., supra note, at 378.

${ }^{98} \mathrm{Id}$.
} 
Black, Douglas, and Frankfurter eventually turned out to be especially frequent dissenters, but their propensity to write separately did not emerge until Stone became Chief Justice. ${ }^{99}$ The same is true of Reed and Murphy. From the data, it does appear that Stone was a necessary condition for these and other justices to write separately. We cannot exclude the possibility that eventually, they would have started to do so. But with this evidence, it seems that an amenable Chief Justice -- a norm entrepreneur in his own way -- might well have been an essential condition for the transformation of 1941. The strong version of "new justices" hypothesis does not fit the facts, but we cannot exclude the possibility that the weak version is correct.

\section{The Judiciary Act of $\mathbf{1 9 2 5}$}

It makes sense to distinguish between a court that is required to hear a large number of cases, including easy ones, and a court that has control over its own docket, and could limit itself to difficult questions. We would expect to see far more consensus within the former court than within the latter. Other things being equal, a court that hears a large percentage of easy cases will both have and show less division than a court that hears a large percentage of hard cases.

For much of its history, the Supreme Court lacked control over its docket, but the Judiciary Act of $1925^{100}$ eliminated mandatory appeals and gave the Court its modern authority over the cases that it hears. As a result, the Court could focus on the difficult cases and decline to deal with the straightforward ones, on which agreement would be standard. We might well expect that after the enactment of the Judiciary Act of 1925, there would be a significant shift in the direction of division, because the Court would, by hypothesis, be dealing with a much larger percentage of hard cases. Actual agreement would be replaced by internal dissent. In an illuminating discussion, Corley et al. insist that the establishment of the discretionary docket was "a key external development that helped usher in a new era of dissensus."101

This is a tempting explanation, and it might provide part of the picture, but there are at least three reasons to think that it is inadequate. First, there was disagreement in the earliest periods of the Court, and as we have seen, a norm of consensus was required to reduce its public expression. Second, an investigation of the docket books of Chief Justice Waite, from the period 1874 through 1888, reveals substantial (private) disagreement within the Court. Apparently the cases were not

\footnotetext{
${ }^{99}$ Id.

100 Judiciary Act of 1925, 43 Stat. 936 (1925).

${ }^{101}$ Corley et al., supra note, at 28.
} 
so easy that the justices could readily agree. ${ }^{102}$ Nonetheless, norms in favor of consensus ended up squelching public disclosure of their disagreements. Third, there was a significant lag between enactment of the Judiciary Act and the transformation of $1941 .{ }^{103}$ Because the relevant patterns were not much changed between 1925 and 1940, we cannot say that the Act was sufficient to produce the new patterns. As Walker et al. put it, "Simply stated, a radical jump in dissent following 1927 is not evident. Dissent rates did not begin their major upward move until the early 1940s."104

None of these points denies that the Judiciary Act might have contributed to the new patterns. History is run only once, so we cannot know for sure, but without the Act, the post-1940 Court might have been able to agree in a significantly higher percentage of cases. Perhaps an actual consensus would have been found, and no norm would have been necessary. Nor can we rule out the view that the Act was a necessary condition for the new patterns. But because disagreement was common (but not expressed publicly) before the Act, and because the norm of consensus persisted for well over a decade after the Act became law, it is not an adequate explanation of what began to happen in 1941.

\section{The Case Mix}

It is reasonable to speculate that some areas are more likely than others to produce a consensus within the Court. In highly technical areas, not raising questions about fundamental values, justices might not care enough to produce separate concurrences or even dissents. The effort might not be worth incurring. ${ }^{105}$ When the stakes seem large, and the cases have historical importance, it might be worthwhile to write on one's own. Producing a separate opinion has a cost, and a recurring question is whether that cost is worthwhile. In answering that question, the nature of the case is highly relevant.

We might speculate that in the 1940s, the Court started to hear different kinds of cases, and those cases were more likely to produce dissents. But a moment's reflection suggests that the speculation is unlikely to provide the entire picture, or even much of it. In the 1920s and 1930s, the Court was hearing some of the most heated constitutional disputes in the nation's history. What is the evidence that the Court would suddenly start to resolve, in the 1940s, a set of cases that produced unprecedented divisions within the Court, and that suddenly prompted justices to write more regularly on their own? There is no evidence that mixes in the cases produced the change in 1941. Starting in that year, the very issues that had produced a consensus under Chief Justice Hughes produced dissents under Chief

\footnotetext{
${ }^{102}$ See Lee Epstein et al., The Norms of Consensus on the U.S. Supreme Court, 45 Am J Polit Sci $362(2001)$.

${ }^{103}$ Walker et al., supra note, at 365-66.

${ }^{104}$ Id. at 366.

$105 \overline{\mathrm{On}}$ the relevance of effort to judicial opinion-writing, see Lee Epstein et al., supra note.
} 
Justice Hughes. ${ }^{106}$ The best conclusion is that norms themselves began to shift, and that changes in the relevant issues were immaterial.

A more specific suggestion might be that in the late 1930s and early 1940 s, economic issues receded in number and importance, and that civil rights and civil liberties cases started to became more common. But here too the speculation runs into an evident problem: Economic issues seemed to split both the country and the Court in the 1930s, and there is no reason to think that such issues would be peculiarly likely to yield to a norm of consensus. Statistical analysis supports this view: In the decades of the 1930s and 1940s, there is no relationship between the decline of consensus and the rise of civil rights and liberties issues. ${ }^{107}$

\section{Protocols}

Some people have attributed the transformation of 1941 to changed protocols within the Court. ${ }^{108}$ In a highly illuminating discussion, G. Edward White notes that "As late as the 1940s, the official United States Reports only identified the author of the 'opinion of the Court' and those Justices who either filed concurring or dissenting opinions or who had themselves identified as either concurring in the majority result or dissenting." 109 It was not until 1947 that the Court adopted the "current practice of listing the votes of all the Justices who participated in a case in the headnote to that case in the United States Reports." 110 White adds that after "the adoption of that protocol, silent acquiescence became a rare phenomenon."111

In addition, and relatedly, the Court began to circulate all opinions in advance. White urges that in part because "all Justices who had joined an opinion of the Court were known,"112 the Court members became more likely to "want to see the language of draft majority opinions before 'signing on.'”113 In White's account, this new protocol "invited concurring and dissenting opinions." 114

The two protocols undoubtedly did matter, but for several reasons, they cannot account for what happened in 1941. First, they occurred in 1947 - fully six years after the new patterns emerged. Second, the new protocols did not develop on their own; they were hardly an external shock. On the contrary, they were produced by the changing preferences of Chief Justice Stone and his colleagues. In that sense, they are better characterized as a product of the transformed court than as a cause

\footnotetext{
${ }^{106}$ Id. at 370.

${ }^{107}$ Stacia Haynie, Leadership and Consensus on the U.S. Supreme Court, 54 J Politics 1159, 1166 (1992).

${ }^{108}$ See White, supra note, at 1502-10.

${ }^{109}$ Id. at 1503.

${ }_{110}$ Id. at $1503-04$.

111 Id. at 1504.

112 Id. at 1505.

113 Id.

$114 \underline{\mathrm{Id}}$ at 1506.
} 
of the transformation. Third, it is most doubtful that if the two protocols had been changed in 1850 or 1900, there would have been a significant problem for the consensus norm or for the idea of silent acquiescence. In the earlier periods, justices had their own convictions and remained silent, in large part on the view that they were willing to acquiesce. There is no reason that silent acquiescence could not occur if the justices had regularly seen and studied the opinions in advance.

\section{Legal realism and the nature of legal reasoning}

It might be thought that the norm of consensus broke down in a period that reflected the power of legal realism: to put it crudely, the view that legal interpretation inevitably involved judgments of policy and principle, and that the law could not simply be "found." 115 When law was taken to be objective - it might be thought - justices would be especially inclined to suppress their own dissent, on the theory that the majority view must be correct, or at least must be taken as such. But when the law seemed to reflect more personal judgments of policy and principle, the argument for self-silencing might seem far weaker. The historian David O'Brien contends that in the late 1930s and early 1940s, the new justices were much affected by arguments about the indeterminacy of the law. According to O'Brien, the post-New Deal Justices, having been schooled in legal realism, "virtually all tended to increase their dissent and concurring behavior during their time on the bench."116

The speculation is reasonable in the abstract, but it does not fit the data well. In Recall that the post-New Deal justices were fairly silent before 1941. Legal realism was not enough to ensure that they would express their separate views in 1937, 1938,1939 , or 1940 , when their voting patterns fit the pattern for the period from 1800. More fundamentally, internal disagreement about the law was common well before the birth of legal realism. ${ }^{117}$ The norm of consensus, strongly challenged by Jefferson, was necessary in the face of those differences. It is hard to defend the idea that in pressing for that norm, Chief Justice Marshall and his successors had some sort of jurisprudential commitment to legal formalism. When the justices suppressed their disagreements, it was not because they believed that the law was determinate, but because they thought that it was important, valuable, or appropriate for the justices to offer a united front. One of Marshall's concerns was legitimacy; there is no evidence that he favored unanimity because of some kind of theoretical belief about the nature of law.

\section{Why Have the Patterns Been Relatively Stable after 1941?}

How do we explain the relative consistency of the relevant patterns over more than six decades? It should be clear that for those patterns to persist, two conditions are necessary. First, the level of actual disagreement must remain

\footnotetext{
${ }^{115}$ See American Legal Realism (William Fisher et al. 1993).

${ }^{116}$ O'Brien, supra note, at 105.

${ }^{117}$ See the important findings in Epstein et al., supra note.
} 
relatively constant. Second, the norms that govern the expression of disagreement must remain relatively constant as well. Let us begin with actual disagreement.

1. Actual disagreement. A potential explanation is that both Democratic and Republican presidents appoint justices, and unless one party dominates the presidency for a sustained period, the Court will be predictably divided between Democratic and Republican appointees - hence a significant amount of division, resulting in dissents, concurrences, and 5-4 splits. This explanation is especially tempting if we focus on the period since 2009, when the Court has included five justices appointed by Republican presidents ${ }^{118}$ and four appointed by Democrats. ${ }^{119}$

The difficulty with this explanation is that comparable levels of disagreement can be found regardless of whether the Court has consisted of a nearly even division of Democratic and Republican appointees, or whether it has consisted largely of appointees from presidents of a single political party. As we have seen, the modern patterns were born in a period in which the Court was dominated by Democratic appointees. And for most of the last three decades, the Court has been dominated by Republican appointees. In 1981, the Court had two Democratic appointees (Thurgood Marshall and Byron White) and seven Republicans (William Brennan, Harry Blackmun, John Paul Stevens, Warren Burger, Lewis Powell, Sandra Day O'Connor, and John Paul Stevens). In 2001, there was a similar 7-2 split in favor of Republican appointees. The percentage of 5-4 splits cannot be shown to have declined when presidents of a single party have been able to select a large majority of the Court's members.

A related explanation is that since the 1940s, the Court has often been evenly divided on ideological grounds, in part because Republican presidents have made some liberal or moderate choices (whether intentionally or by mistake). There is no question that William Brennan (an Eisenhower appointee) and Harry Blackmun (a Nixon appointee) showed quite liberal voting patterns. ${ }^{120}$ Many Republicans were disappointed by Stevens (a Ford appointee) and David Souter (appointed by George H.W. Bush). ${ }^{121}$ Perhaps the relative consistency of internal divisions is a product of persistent ideological splits within the Court.

There is something to this explanation, but it is not adequate. To see why, consider a thought experiment. Let us imagine that over the next decade, the Court shifts significantly to the right. Suppose that the only two retirements come from Justices Breyer and Ginsburg, and that they are replaced by people who tend to agree with Justices Scalia and Thomas. In that event, the Court's center of gravity would shift dramatically, with an apparent "bloc" of six conservatives (Scalia,

\footnotetext{
118 John Roberts, Clarence Thomas, Antonin Scalia, Anthony Kennedy, and Samuel Alito.

${ }^{119}$ Ruth Bader Ginsburg, Stephen Breyer, Sonia Sotomayor, and Elena Kagan.

${ }^{120}$ See Epstein et al., supra note, at Table 3.4 (ranking justices from most to least conservative by three measures).

${ }^{121}$ See id.
} 
Thomas, Roberts, Alito, and the two new members). Should we expect to see a sharp reduction in internal divisions?

The answer is not necessarily, and for one reason: Lawyers and lower court judges are alert to the composition of the Court. If the Court shifts in any particular direction, we will almost certainly see very different set of rulings in the lower courts, whose judges are most unlikely to issue decisions that are overwhelmingly likely to be reversed. The central point is that the cases that the Court hears will consist, in large part, of issues that are difficult not in the abstract, but in light of the Court's particular composition at the time. It follows that in the modern era, a significant level of (actual) internal disagreement is highly likely to persist, and that unless the justices adopt a norm in favor of consensus, any Supreme Court will probably seem divided in a significant number of important cases. The reason is that in a hierarchical legal system, the Court will end up hearing disputes that are likely to split its current members - and this is true even if their approach to the law, or their ideology, changes radically over time.

2. Expressed disagreement. Why has the norm itself remained relatively stable since 1941? A full account might well have to distinguish among periods; the persistence of the norm in the 1980s might not have the same explanation as the persistence of that norm in the 1990s or 2000s. To investigate such questions, a detailed historical account might well be necessary. But the simple and most general answer is that the justices have not had a sufficient motivation to alter it. The question is what individual justices prefer. From their standpoint, the costs of returning to the pre-1941 norm would apparently be high, because the result would be a significant degree of self-silencing. Of course those costs might be worth incurring if the justices also had a high degree of "effort aversion."122 Recall that on one account, the early triumph of the norm on the Marshall had something to do with such aversion. ${ }^{123}$ But there is no reason to think that any effort aversion would be sufficient to lead members of the Court to favor a consensus norm.

It is certainly imaginable that a chief justice could produce some movement in the direction of that norm. We lack direct evidence that any chief justice has tried, in any serious or systematic way, to restore such a norm, and in any case there is reason to wonder whether any such effort would be likely to succeed. For over seventy years, justices have generally felt free to express their views, and any norm in favor of self-silencing appears to have been weak (though we cannot exclude the possibility that it exists in some moderate form). With a longstanding tradition in favor of the current patterns, a chief justice would have to be both ambitious and exceedingly skillful if he sought to move toward the pre-1941 norm. As noted, Chief Justice Roberts is on record as favoring a reduction in separate opinions and an increase in unanimity, ${ }^{124}$ but from 2006 through 2012, he was unable to produce

\footnotetext{
${ }^{122}$ See id.

${ }^{123}$ See supra.

${ }^{124}$ See note supra.
} 
any change in the relevant patterns. It remains to be seen whether the evident increase in unanimity, in the 2013 term, suggests that he is having some success.

\section{Evaluating the Modern Era}

Expressed disagreement will have both benefits and costs. It is important to see that from the standpoint of the individual justice, the calculation may be very different from what it is from the standpoint of society as a whole. To understand the judgments of individual justices, we need to know what they maximize. ${ }^{125}$ For example, some justices may not want to expend a great deal of effort, and hence "effort aversion" might lead them not to write separately (and to favor and promote a norm of consensus). ${ }^{126}$ Other justices might care greatly about their reputations, perhaps their personal legacy, and if they do, they will be more likely to stake out their own ground (and to favor and promote a norm in favor of separate statements). For that reason, self-expression may not promote social welfare, at least if justices do not give adequate consideration to the social costs of internal division. Justices also care about the development of the law as such, which will motivate them to take social welfare into account, and perhaps to treat it as the most important consideration. My analysis here focuses principally on social welfare as such, rather than on the calculus for individual justices.

Let us start with benefits, signaled by Jefferson's early complaint and captured briefly in Justice Brennan's suggestion: “Through dynamic interaction among members of the present Court and through dialogue across time with the future Court, we ensure the continuing contemporary relevance and hence vitality of the principles of our fundamental charter."127

\section{A. The Benefits of Disagreement}

If we disaggregate the principal benefits, they seem to fall in three categories.

1. Future adjudication. With respect to benefits, the most important point is that a dissent ${ }^{128}$ might turn out to have desirable effects on the future development of the law. Perhaps justices will eventually it persuasive; it might provide a kind of lodestar for posterity. Indeed, numerous dissents have become the law of the land. ${ }^{129}$ As Justice Brennan wrote, a dissent "is offered as a corrective -- in the hope

\footnotetext{
${ }^{125}$ See Epstein et al., supra note.

${ }^{126} \mathrm{Id}$.

${ }^{127}$ Brennan, supra note, at 438 .

${ }^{128}$ The points made here apply to concurrences as well - certainly concurrences in the judgment, but also concurrences that reflect a somewhat different orientation from the majority opinion.

${ }^{129}$ Prominent examples include Lochner v. New York, 198 U.S. 45, 75 (1905) (Holmes, J., dissenting); Plessy v. Ferguson, 163 U.S. 537, 551 (1896) (Harlan, J., dissenting); Abrams v. United States, 250 U.S. 616, 624 (1919) (Holmes, J., dissenting); Minersville School Dist. v. Gobitis, 310 U.S. 586, 601 (1940) (Stone, J., dissenting); Olmstead v. United States, 277 U.S. 438, 471 (1928) (Brandeis, J., dissenting). For the total numbers, see infra.
} 
that the Court will mend the error of its ways in a later case."130 In many cases, dissenters undoubtedly hope that their views will end up producing such a corrective.

To evaluate this point in a disciplined way, it is necessary to focus on two factors: the likelihood that a dissent will have that effect and the value of the effect if it should occur. If the real goal is to alter the course of the law, it is not worth producing a dissent if the chance of alteration is zero. But even if the chance is relatively low, it might be worth writing separately if the value of a change is extremely high. These simple points help to explain the intuitive point that in cases of great importance, where a justice believes that the Court has made a damaging and harmful mistake, the incentive to dissent is increased. Even in the pre-1941 era, justices appear to have produced dissents in part for this reason. ${ }^{131}$ From the social point of view, a dissent has an "expected value" in terms of effects on future justices, and in some cases, the expected value might be high.

We should distinguish here between two kinds of effects on future adjudication. In the most dramatic cases, the Court's opinion is actually overruled.132 In less dramatic cases, the Court's opinion is read narrowly, or at least not expanded. A powerful dissent might be worthwhile if it has the latter consequence. Indeed, a dissent might be written specifically to have that consequence. Here as well, there is an expected value in terms of benefits, and it might be high.

2. Congress. Even if a dissent is not likely to move a future Court, it might influence Congress. ${ }^{133}$ If a justice signals that the Court has erred and that the stakes are high, she might trigger legislative attention. ${ }^{134}$ Here again, a prospective dissenter would do well to consider both the probability that a dissent will have that effect and the value of the effect if it should occur. In the abstract, it is reasonable to think that legislators are significantly more responsive to results than to dissenting opinions, and that dissents will, at most, create a modest increase in the incentive to correct what legislators would already see as a mistake or an injustice. Justices who believe that separate opinions, as such, will have large effects on Congress might be suffering from optimistic bias ${ }^{135}$ or the spotlight effect. ${ }^{136}$ But even if a dissenting opinion increases the likelihood of a legislative response only modestly, its expected value might be high.

\footnotetext{
${ }^{130}$ Brennan, supra note, at 430 .

${ }^{131}$ See the citations in note supra.

${ }^{132}$ See infra for numbers.

${ }^{133}$ It could have similar effects on state legislatures, for which the analysis would be essentially the same.

${ }^{134}$ See Ginsburg, supra note. Here as well, the point applies to separate concurrences as well as to dissents.

${ }^{135}$ See TAli SHAROT, THE OPTIMISM BiAs (2011).

${ }^{136}$ See Thomas Gilovich et al., The Spotlight Effect in Social Judgment: An Egocentric Bias in Estimates of the Salience of One's Own Actions and Appearance, 78 J Pers and Social Psych. 211 (2000).
} 
3. The chastened majority? Even if a dissent has no influence on future justices or Congress, it might improve the majority opinion, perhaps by ensuring that certain arguments are met with plausible answers, or perhaps by convincing the justices in the majority to scale back their opinion or to move it in different directions. ${ }^{137}$ In these ways, a dissent can fortify the participation of the litigants and also improve both prevailing opinion and the ultimate result.

Of course it is true that having done that work, the author of a dissenting opinion might choose not to publish what she wrote - but the effects of a dissent might well depend on a credible commitment to publish. We lack systematic evidence with respect to the claim that dissenting opinions improve or even materially alter opinions of the Court. For obvious reasons, such evidence would be exceedingly difficult to compile. But it is more than plausible to think that both the possibility and the actuality of dissenting opinions have a beneficial effect on the Court's majorities.

Those who object to internal division are likely to contend that these various benefits are overstated. But their principal concern, traceable to Marshall's era, involves the costs of division. Like the benefits, the costs appear to fall in three different categories; each of them requires extended treatment.

\section{B. Credibility, Legitimacy, and "Monolithic Solidarity"}

In calling for a "refocus on functioning as an institution," Chief Justice Roberts said that with its post-1941 patterns, the Court risked a loss of "its credibility and legitimacy." 138 As he saw it, internal divisions could threaten the Court's image in the eyes of the public. Learned Hand saw things similarly, writing that a dissenting opinion "cancels the impact of monolithic solidarity on which the authority of a bench of judges so largely depends."139

1. Hypotheses. Whenever the Court is not unanimous, we might speculate that its credibility is at risk, because a competing view will be offered, and it might be expressed vigorously. Brown v. Board of Education was famously unanimous, and Chief Justice Warren worked exceedingly hard to ensure that the nation would see that the justices were in total agreement. ${ }^{140}$ In his view, a divided Court would sacrifice its legitimacy in an area where legitimacy was crucial. ${ }^{141}$ And it is hardly implausible to think that from the standpoint of legitimacy, 5-4 divisions are especially troubling, because they suggest that with a change of a single vote,

${ }^{137}$ See Ginsburg, supra note.

${ }^{138}$ See note supra.

139 L. HAND, THE BILL OF RIGHTS 72 (1958).

${ }^{140}$ See generally Richard KLUGer, SimPle Justice: THE History OF BROWN V. BOARD OF EDUCATION AND BLACK AMERICA's STRUGGLE FOR EQUALITY (2004).

${ }^{141} \mathrm{Id}$. 
fundamental issues might have been resolved differently. The problem might well be aggravated if the division occurs along predictable political lines. Bush v. Gore $e^{142}$ is perhaps the most extreme example - on this count, the anti-Brown -- because the Court's majority consisted solely of Republican appointees, and because the ultimate result was widely seen as highly politicized. ${ }^{143}$

This concern is actually a hypothesis, to the effect that internal divisions weaken credibility. The hypothesis raises empirical questions: Are 5-4 decisions genuinely less credible than unanimous decisions, and if so, to what extent? Are 5-4 decisions less credible than 7-2 decisions, or than 8-1 decisions? In principle, those questions should be answerable. Brown was indeed unanimous, but its unanimity did not come close to quelling public opposition. ${ }^{144}$ Perhaps the opposition would have been even worse if the Court had been divided -- but perhaps not.

Consider a competing hypothesis: The credibility of Supreme Court decisions does not turn on the extent of the division within the Court, but instead on the relationship between those decisions and the prior convictions of relevant members of the public. Under this hypothesis, everything depends on whether the Court's decision is consistent with people's prior convictions. If the Court ruled that the Constitution gives the Environmental Protection Agency the power to arrest and imprison people at its whim, the public would be most unlikely to find the decisions credible and legitimate, even if the Court turned out to be unanimous. If, by contrast, the Court issued a ruling that is broadly acceptable, and that fits with widespread convictions, the public will not be much exercised whether its ruling is 9-0 or 5-4. And if the public is itself divided, the credibility of the Court's decision will depend on the relationship between those divisions and that decision. If the Court rules in favor of gun control, those who support gun control will find the decision credible, and those who reject gun control will not. On this view, people's prior convictions are what matter, not vote-counting.

Existing evidence remains sparse, but it tends to support this hypothesis. Larger majorities and unanimity do not seem to increase public acceptance of the Court's decisions. A 2009 study explored people's reaction to the controversial decision in Kelo v. City of New London. ${ }^{145}$ The presentation of the case was manipulated to change the size of the majority (which was actually 5-4). The results showed that the level of internal consensus had little effect on people's views. ${ }^{146}$ In a later study, Salamone found that "reaction to judicial consensus is dependent on the ideological salience of the issue involved" and that "the public is unmoved by the

\footnotetext{
142531 U.S. 98 (2000).

${ }^{143}$ See note supra.

${ }^{144}$ See Kluger, supra note.

145545 U.S. 469 (2005).

${ }^{146}$ Michael F. Salamone, Supreme Court Unity and Public Opinion: An Experimental Study, APSA 2009 Toronto Meeting Paper (2009).
} 
majority size in highly salient decisions."147 It is only in "cases with low salience" that large majorities have an effect on public attitudes. ${ }^{148}$ The distinction between "high salience" and "low salience" has a close connection to the question whether people have clear antecedent convictions. When a case is highly salient, it is because it raises issues that trigger strong concerns. When it has low salience, it is because it does not much matter to them, and hence their antecedent convictions are weak.

To say this is not to insist that in highly salient cases, internal divisions do not matter at all. The existing evidence does not exclude the possibility that a unanimous decision can increase legitimacy and reduce concerns about politicization within the Court. Some people might well seize on any kind of dissent to show that their disagreement is reasonable, and a 5-4 decision (with a predictable division along ideological lines) might seem, to some citizens, less convincing than a unanimous or lopsided vote. Certainly a dissenting opinion can serve as a rhetorical resource for those who object to a decision.

In the future, we should be able to obtain more evidence on the question whether 5-4 decisions are, in fact, less credible than other kinds of decisions. To be sure, we do not have randomized controlled trials, enabling us to explore whether (for example) Citizens United, ${ }^{149}$ Heller, ${ }^{150}$ or NFIB v. Sebelius ${ }^{151}$ would have been less controversial if the Court had been undivided or less divided. But an experimental design could easily explore the question whether the public would receive these decisions, or related ones, differently with larger majorities. At the present time, the idea that 5-4 decisions pose a serious problem of credibility or legitimacy remains an unproven hypothesis.

2. Normative considerations. The second problem is normative. Suppose that a 5-4 decision is, in fact, less credible, and less likely to be perceived as legitimate, than a 9-0 decision. Does that fact suggest that justices should decline to express their doubts and join an opinion that they believe to be wrong? The answer is far from obvious. On the one side is the cost of self-silencing: Failing to provide the public with information that could inform its judgment about the underlying issues, and perhaps affect legislation, while also failing to provide posterity, including other justices, with that information as well. On the other side is the benefit: Insulating the Court from criticism that it would otherwise receive. But how much of a benefit is that? Such insulation might well be unwarranted because there is, by hypothesis, internal disagreement on the Court. Is it appropriate to insulate the Court from criticism, and from a challenge to its credibility, that would come from exposing that disagreement to public view? The answer is by no means clear.

\footnotetext{
${ }^{147}$ Michael F. Salamone, Judicial Consensus and Public Opinion: Conditional Response to Supreme Court Majority Size, 20 Political Research Q. 1 (2013).

${ }^{148}$ Id. at

${ }^{149}$ Citizens United v. Federal Election Commission, 558 U.S. 310 (2010).

${ }^{150}$ District of Columbia v. Heller, 554 U.S. 570 (2008).

${ }^{151}$ National Federation of Independent Business v. Sebelius, 567 U.S. (2012).
} 
We might want to make a distinction between a new court, initially struggling to establish its legitimacy, and a court whose essential legitimacy is clear and not truly contested. For the former court, there might well be an argument for reducing the appearance of internal contestation. The same might also be said of an established court that is resolving a highly contested question. As noted, Brown v. Board of Education ${ }^{152}$ is the most famous example; Chief Justice Warren believed that a divided court would fuel opposition. ${ }^{153}$ As also noted, many people lamented the 5-4 division in Bush v. Gore, contending that the split vote suggested a high degree of politicization on questions of constitutional law. ${ }^{154}$ In some cases, unanimity might reduce that concern - though as noted, this is an empirical question on which it is difficult to have much confidence. In general, we lack evidence to justify the belief that the post-1940 patterns have raised serious questions about the Court's legitimacy and credibility. ${ }^{155}$

\section{Stability and Certainty}

Stability in judge-made law can be important, in part because those affected by law can benefit from a high degree of certainty. On this view, the problem with divided rulings is that they are fragile. It might be urged that the pre-1941 situation was better precisely because the Court's rulings were more fixed and firm. Note that this objection turns into a vice what supporters of dissenting opinions see as a virtue: the possibility that a dissenting opinion will eventually move the law.

This concern can take three different forms. The first is that when the Court is divided, its decisions are more likely to be overruled. The second is that when the Court is divided, its decisions are more likely to be cabined, perhaps limited to their facts, and hence the law is more likely to take a meandering and unpredictable path. On this view, split rules will ensure a kind of case-by-case minimalism, not

${ }^{152}$ Brown v. Board of Education, 347 U.S. 483 (1954).

${ }^{153}$ See Kluger, supra note.

${ }^{154}$ Many examples can be found in Bush v. Gore: The Court Cases and the Commentary (E.J. Dionne and William Kristol eds. 2001).

${ }^{155}$ There are interesting comparisons here with the legislative and executive branches. Within Congress, there is no norm in favor of silent acquiescence, at least not on controversial issues; votes are publicly recorded and debates are substantive and often heated. In general, no one argues for a norm of consensus. (Compare, however, the idea of "unanimous consent," which allows some confirmation votes, and the enactment of some legislation, to occur with a roll call vote.) Within the executive branch, the practice is the opposite. If, for example, the Secretary of Transformation and the Director of the National Economic Council disagree with the President on some question, their views are unlikely to be made public, and they might well defend the President's decision even though they disagree with it. Within the executive branch, silent acquiescence is the rule, perhaps because of an understanding that the President is authorized to make the ultimate decision, and any public expression of disagreement would be a form of insubordination. For the constitutional background, see Myers v. United States, 272 U.S. 52 (1926). 
necessarily when they are issued, but as subsequent courts work to narrow them. The third concern is that litigants and lower courts are less likely to know what the law is; they are more likely to be confused. All of these concerns raise empirical questions.

1. Overruling? With respect to the first, we have some quantitative evidence, and it does support the claim that when the Court is sharply divided, its decisions are more fragile. ${ }^{156}$ One study, analyzing data from 1946-1995, finds that a precedent is more likely to be overruled if it is the product of a one-vote margin decision; a precedent is less likely to be overruled if its decision coalition was unanimous; and the larger the number of concurring opinions published with a precedent, the greater the chance it will be overruled. 157 More specifically, a minimum winning coalition increases the risk of overruling by 53.6 percent, and a unanimous coalition decreases the risk of overruling by 46.9 percent. ${ }^{158}$ For each additional concurrence, the risk of the case being overruled increases by 22.4 percent. ${ }^{159}$

These are large differences, but percentages should be taken with many grains of salt. The Court overrules very few of its decisions, and hence the risk that any particular decision will be overruled is exceedingly low. Even if the risk increased by 50 percent or more, it is still exceedingly likely not to be overruled. More specifically, the Court has, in its history, overruled 1.2 percent of its decisions, and 1.7 percent of its 5-4 decisions. ${ }^{160}$ From the social standpoint, how meaningful is the relevant increase in probability? We do not even know that the 5-4 division causes the increase. It may be that 5-4 splits reflect the importance and difficulty of the underlying questions, and hence that cases that pose such questions would be more likely to be overruled even if they were unanimous.

To evaluate this evidence, moreover, we would have to distinguish between 9-0 decisions that reflect actual agreement and 9-0 decisions that reflect silent acquiescence. A norm of consensus means that dissenting justices will generally join the majority, notwithstanding their private views, and do not express those views in public. But they are nonetheless dissenters. An apparent 9-0 decision may be, in reality, a 5-4 split. Would the justices be less likely to overrule a secret 5-4 decision

\footnotetext{
156 ThOMAs G. HANSFORd \& JAMES F. SPRIgGS, The POLITICS OF PRECEDENT ON THE U.S. SUPREME COURT 90-92 (2006).

${ }^{157}$ James F. Spriggs, II \& Thomas G. Hansford, Explaining the Overruling of U.S. Supreme Court Precedent, 63 J. Politics 1091, 1104-05 (2001).

${ }^{158}$ Id. at 1105.

159 Id.

${ }^{160}$ Congressional Research Service. "Supreme Court Decisions Overruled", Constitution of the United States of America: Analysis, and Interpretation - Centennial Edition - Interim, S. Doc. 112-9, issued June 26, 2013, available at http://www.gpo.gov/fdsys/pkg/GPO-CONAN2013/pdf/GPO-CONAN-2013-13.pdf. (entire report available at: http://www.gpo.gov/fdsys/search/pagedetails.action?granuleId=\&packageId=GPO-CONAN2013\&fromBrowse $=$ true).
} 
that a publicly expressed 5-4 decision? Perhaps so, but the existing evidence does not enable us to answer that question.

2. Cabining? It is certainly plausible to think that when the Court is sharply divided, the Court itself, or lower courts, are more likely to read its opinion narrowly. Consider, for example, Bush v. Gore, which has not produced a set of new equal protection cases or spawned doctrinal departures ${ }^{161}$-- perhaps in part because of the internal division. If we disapprove of a situation in which constitutional law moves in fits and starts, with decisions that are limited to their facts, we might be especially concerned about internal division. The problem of uncertainty is the foundation of that concern.

Here as well, however, we need to begin by asking a question about the relevance of a norm of consensus: Are decisions that hide secret divisions, in which justices do not reveal their disagreement, less likely to be cabined than decisions with publicly expressed divisions? Perhaps lower courts and litigants care about what is expressed, because that is all that they see - a point that may argue for a increase in expressed unanimity. But within the Court itself, a division is a division, whether or not it is revealed to the public. For obvious reasons, it is not easy to study the question whether the justices are likely to read a decision narrowly if the justices are divided but do not disclose that fact.

In terms of how the Court reads its own decisions, two questions would seem to be central. The first is whether members of a majority - whether it is 5-4, 7-2, or 9-0 -- are ambivalent about the reasoning and the result. The number of justices who join the opinion may tell us very little about that question. If the justices are divided $5-4$, and if the members of the majority have issued a broad, declarative statement in which they have full confidence, there is not much reason to think that the ruling will be read narrowly. ${ }^{162}$ The second question is whether the composition of the Court changes over time. Changes in the Court's composition can of course lead to significant shifts in the law. ${ }^{163}$

It is true that if one member of a 5-4 majority reads the decision very narrowly, and joined it on that understanding, a degree of cabining is highly likely. But would things be different if the four dissenters declined to express their views and thus made for a unanimous majority? It might be expected that with a norm of consensus, we would have to distinguish between real 9-0 decisions and 9-0 decisions that reflect silent acquiescence. Apparent 9-0 decisions, which are in fact 5-4 decisions,

\footnotetext{
161 For relevant discussion, see Richard Hasen, Bush v. Gore and the Future of Equal Protection Law in Elections, 29 Fla State Univ L Rev 377 (2001).

${ }^{162}$ An arguable example is Kelo v. City of New London, 545 U.S. 469 (2005).

${ }^{163}$ For a set of illustrations, see Cass R. Sunstein, Why Does the American Constitution Lack Social and Economic Guarantees? (2003), available at http://papers.ssrn.com/sol3/papers.cfm?abstract_id=375622
} 
should produce the same future path as 5-4 divisions that are publicly disclosed as such.

Suppose it is true that when the Court is publicly divided 5-4, or when dissents are common, precedents are read more narrowly. Is that a problem? As we shall soon see, some people favor unanimous opinions precisely because they produce greater narrowness. ${ }^{164}$ Whether narrowness is a problem, or instead a kind of solution, depends on the context.

3. Uncertainty? Does a divided Supreme Court increase uncertainty? We can imagine extreme cases in which the answer is obvious. If there is no majority opinion, and if six different justices write separately, it might be exceedingly difficult to know what the law is. That is a genuine problem. The law cannot be certain if there is no opinion for the Court. ${ }^{165}$ But is there also uncertainty in the presence of some number of concurrences and dissents, or with a 5-4 division?

The answer is by no means clear. We can easily imagine a 9-0 decision that leaves a great deal of uncertainty, perhaps because it is vague and ambiguous, or perhaps because it is narrow and limited to the particular facts. A decision that employs a multifactor balancing test might well leave the law up for grabs, no matter how many justices agree to it. ${ }^{166}$ By contrast, a 5-4 decision might establish a clear, firm rule, one that everyone understands. If, for example, the Court ruled that the Constitution gives people the right to enter into same-sex marriages, or does not protect commercial advertising, the law would not be ambiguous, and people would have no need to guess. With respect to certainty, the most important question is the nature of the opinion and the judgment, not the number of justices who sign it.

4. Normative questions. There is a normative question as well. Stability and certainty can be important, to be sure, but their importance differs across areas, and in the abstract, any incremental instability produced by 5-4 rulings need not be seen as decisive. Of course it is true that some areas of law need to be settled, so that people can organize their affairs, and it is acceptable if existing decisions are not ideal in principle. But if such rulings are badly wrong, and do significant damage, there is a strong argument in favor of destabilizing them. Indeed, a 5-4 division may itself be evidence that a decision deserves continuing scrutiny.

The argument from stability and certainty rests on weak foundations. From the standpoint of those very goals, apparent unanimity, disguising internal division, is not much better than a 5-4 ruling, and the goals are themselves an ingredient in the overall analysis, and hardly trump cards.

\section{Minimalism}

\footnotetext{
${ }^{164}$ See infra.

${ }^{165}$ See, e.g., Crawford v. Marion County Election Bd., 553 U.S. 181 (2008).

166 Antonin Scalia, The Rule of Law As A Law of Rules, 56 U Chi L Rev 1175 (1989).
} 
Judicial minimalists think that judicial decisions should be narrow rather than wide, in the sense that judges should answer the question at hand, and ought not to not reach out to answer other questions that are not, strictly speaking, necessary for the decision. ${ }^{167}$ Minimalists also want judicial decisions to be shallow rather than deep, in the sense that judges try to produce rationales on which people can agree even if they disagree about foundational questions, or do not know what they think about such questions. On one view, the Supreme Court should aim for minimalism, on the ground that it reduces the costs of decisions and the risks of error, and fits with the appropriate role of federal judges in a democratic system. ${ }^{168}$

It is not clear, however, that justices should embrace minimalism, especially if they favor certainty ${ }^{169}$; there is an unmistakable tension between the two goals. To this extent, it is difficult to favor unanimous decisions on the ground that they increase certainty while also favoring such decisions on the ground that they promote minimalism. But suppose that justices do embrace minimalism. If so, they might be skeptical of divided courts, and approve of a norm that encourages the justices to find a rationale on which all can agree. Chief Justice Roberts has pressed this particular point, urging that the "broader the agreement among the justices, the more likely it is a decision on the narrowest possible grounds." 170

To see his point, imagine that the Supreme Court were currently governed by an unambiguous norm in favor of consensus. Such a norm might well incline the majority in the direction of taking on the concerns of the skeptics, producing narrow, shallow opinions. If the Court could not issue an opinion without broad or universal agreement - if the skeptics had something akin to a veto power -- width and breadth would become far less likely. Some examples from history: Instead of ruling that the Constitution protects a rule of one person, one vote, ${ }^{171}$ the Court would be more likely to rule that any departures from that rule must have some kind of non-arbitrary justification. ${ }^{172}$ Instead of creating a broad right to choose abortion, ${ }^{173}$ the Court might have struck down relevant state laws as unduly vague, or as unacceptable insofar as they prohibited abortion in cases of rape and incest. ${ }^{174}$

${ }^{167}$ See generally CASs R. SUnStein, OnE CASE AT A Time (1999).

${ }^{168}$ For competing views on that question, see id.; Antonin Scalia, The Rule of Law As A Law of Rules, 56 U Chi L Rev 1175 (1989).

${ }^{169}$ See Scalia, supra note.

${ }^{170}$ Quoted in Chief Justice Says His Goal is More Consensus on the Court, N.Y. Times, May 22, 2006, at A16. From John Roberts's commencement address at Georgetown University Law

Center.

${ }^{171}$ Reynolds v. Sims, 377 U.S. 533 (1964)

${ }_{172}$ As suggested in id. at 565 (Stewart, J., concurring).

${ }^{173}$ See Roe v. Wade, 410 U.S. 113 (1973).

${ }^{174}$ For an argument in favor of a narrow approach to the abortion question, at least when the Court initially confronted that question, see Ruth Bader Ginsburg, Some Thoughts on Autonomy and Equality in Relation to Roe v. Wade, 63 N.C. L. REV. 375 (1985). 
And indeed, the logic of Chief Justice Roberts' view is that he would approve of the direction toward greater narrowness and shallowness.

It follows that for those who favor minimalism, there is a plausible instrumental argument in favor of a norm of consensus. But even on its own terms, the argument is not airtight. If such a norm is in play, the question is whether the majority must accommodate the views of the minority, or whether the minority must instead surrender. By itself, the norm of consensus is agnostic on that question. If the norm encourages the minority to surrender, then broad, deep rulings can be expected even from unanimous courts - an outcome that is, from the standpoint of minimalism, actually perverse.

The deeper problem is that minimalism should not always be favored. ${ }^{175}$ This is not the place to discuss that question in detail here, but the argument on behalf of minimalism depends largely on the costs of decisions and the costs of errors. ${ }^{176}$ In some cases, narrowness is a vice rather than a virtue, because it leaves uncertainty and unpredictability, and because a wider ruling would reduce both without introducing error. In some cases, depth is desirable, ${ }^{177}$ because it gives a clear sense of the grounds for the outcome, and offers a sound basis for future development. Minimalism is not an approach for all times and seasons. It follows that even if a norm of consensus would press the Court in the direction of minimalism, it is not clear that the norm is desirable.

\section{E. A Brief Accounting}

These various considerations show that from the social point of view, a division within the Court will have both benefits and costs. Improvements in the course of the law unquestionably count as benefits, and separate opinions can lead to such improvements. But as a general rule, a dissenting opinion, or a 5-4 division, is unlikely to lead a future Court to overrule a prior decision, if only because the Court rarely overrules itself. Perhaps an internal division, and a public expression of disagreement, can make the Court less likely to expand on a contested ruling, but that conclusion is itself speculative. Moreover, the likelihood that a dissent, or a 5-4 division, will increase the likelihood of congressional action is quite low. To be sure, even a small increase in the probability of overruling, or of a congressional response, might justify a dissent if the stakes are high, and if the costs of such a dissent are themselves low. And in many cases, the strongest arguments on behalf of separate opinions - both concurrences and dissents -- might well be that they can produce improvements in the reasoning and the reach of the majority opinion.

\footnotetext{
${ }^{175}$ Scalia, supra note.

${ }^{176}$ A valuable, related discussion is Louis Kaplow, Rules Versus Standards: An Economic Analysis, 42 Duke L.J. 557 (1992).

${ }^{177}$ Ronald Dworkin, Law's Empire (1985), can be understood as an extended plea for depth.
} 
Separate opinions and internal divisions can have costs as well. If a judgment lacks a majority opinion, there is likely to be a high level of uncertainty. Decisions with 5-4 splits appear to be somewhat more likely to be overruled. Divisions can increase instability. In some cases, minimalism is indeed desirable, and on plausible assumptions, unanimity breeds minimalism. But these points must be taken with considerable caution. On inspection, the standard arguments against separate opinions and internal divisions depend on empirical assumptions that are unlikely to hold true.

In particular cases, the various benefits and costs could be formalized into the foundation for an analysis of whether separate opinions and internal divisions are undesirable. But the broader conclusion is clear: As a general rule, a conscientious justice ought not to silence herself for fear that the costs of a separate opinion will be high. To be sure, the Court's legitimacy might be at risk if it rules in ways that deeply offend the American public, or if large segments of that public perceive themselves as consistent losers. But separate opinions, as such, are unlikely to threaten the Court's legitimacy, certainly not in specific cases, and probably not even across a wide range of cases.

\section{Conclusion}

My three goals here have been to show that in an important respect, the Supreme Court has had two separate eras; to explain the observed patterns; and to evaluate contemporary practice. Before 1941, the Court operated by a norm of consensus. While there were modest variations across time, the norm was essentially intact for 140 years. Starting in 1941, that norm broke down. With respect to dissents, concurrences, and 5-4 decisions, the patterns established in the early 1940s have remained remarkably constant over a long period of time, including the service of forty justices and six chief justices. For the most part, the year-to-year variations, and the differences across the six chief justices, have not been statistically significant. The longer time-scale trends have been both modest and gradual. The dramatic increase in unanimity in the 2013 term is an intriguing exception; it is too soon to say whether it signals a shift from the post-1941 norm.

The best explanation for the transformation of 1941 focuses on two developments: the elevation of Harlan Fiske Stone to the position of Chief Justice in that year and the appointment of seven new justices to the Court between 1937 and 1941. If the new Chief Justice had been insistent on maintaining a norm of consensus, he might well have succeeded, especially in light of the weight of tradition. And if Stone had become Chief Justice in a court dominated by members who were accustomed to the old norm, and tended to favor it, that norm might have been maintained. But Stone himself opposed the norm, and he practiced his opposition. Other justices turned out to be willing and perhaps even happy to jettison the longstanding practice. 
In the post-1941 period, there is no evidence that the justices themselves have disapproved of the new norm, and it would not be easy for a Chief Justice to seek to restore the old one. Hence the patterns established in the early 1940s have remained relatively constant over time - with the interesting and still-puzzling example of 2013.

It is tempting to lament the post-1941 period and to suggest that the old norm promoted credibility and legitimacy, helped stabilize the law, and increased the likelihood of minimalist rulings. No one should deny that if the Court is persistently fragmented, and if the fragmentation occurs along political grounds, some people will lose faith in it - especially if their preferred views are consistently rejected. In any particular historical period, an analysis of the costs and benefits of internal division may argue for an increase in self-silencing. We have seen, however, that the arguments in favor of higher levels of consensus rest on fragile empirical foundations. The post-1941 norm cannot be shown to compromise the Court's role in American government, or to disserve the constitutional order. 


\section{APPENDIX}

Testing the Significance of the Difference Between the 2013 Term and Previous Terms

The change in the trends that was observed in the 2013 Term was quantified by calculating the likelihood that those numbers would be observed if the "true" rate were taken from the rate that has been observed from 1941-2012. The simplest way to do this would be to assume that all variation was due to binomial sampling around a constant overall rate, making the simplifying assumption that every case has the same probability of being decided unanimously. For example, based on the overall percentage of cases decided unanimously from 1941-2012, the "true" rate would be assumed to be $38.2 \%$.

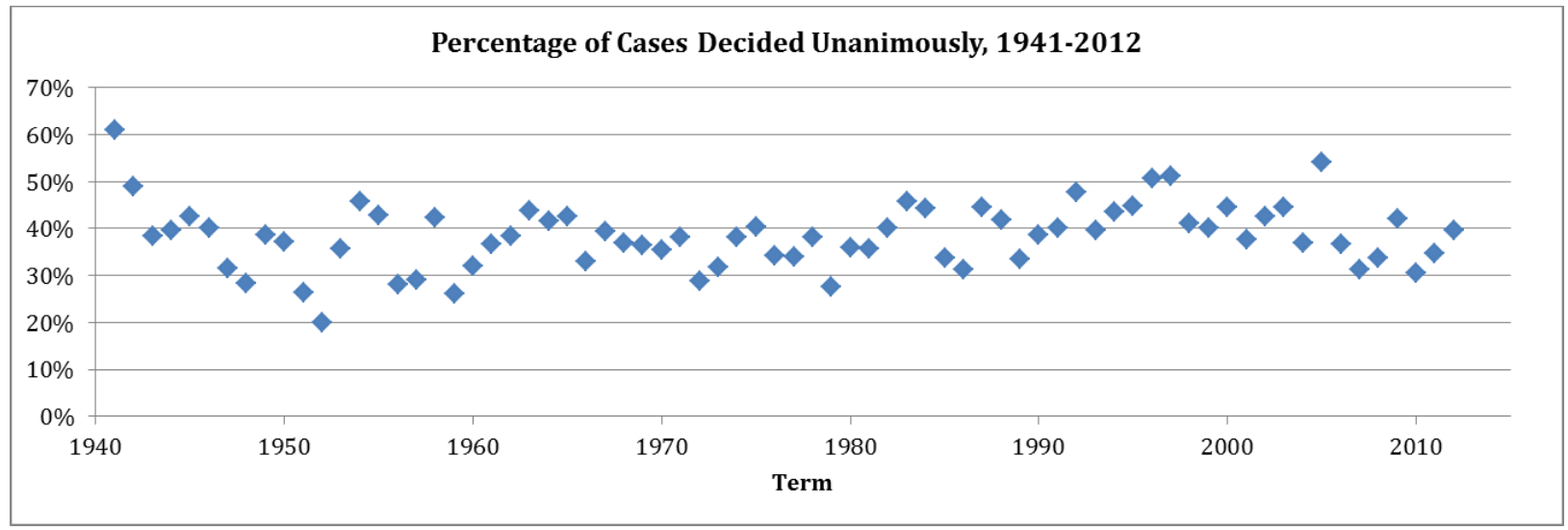

However, more variance was observed in the 1941-2012 data than that simple model would predict. This was determined by simulating 10,000 time series of unanimous decisions, fixing the number of cases each year at their true value. The variance in the fraction of unanimous decisions for each simulated time series was calculated. The observed variance is larger than the variance for any simulated time series, indicating that the data are overdispersed relative to the simple binomial model. Thus, the simplest model would underestimate the probability of very high and very low numbers of unanimous decisions.

For this reason, the simple binomial model was generalized to allow the underlying probability of a unanimous decision to vary independently from year to year. This was modeled with a beta-binomial distribution: Each year, the underlying rate is drawn independently from a beta distribution and then the number of unanimous decisions is drawn from a binomial distribution using that rate. This model treats every year as exchangeable-so it assumes that there are no trends or year-to-year correlations. The maximum likelihood parameters of the beta distribution ( $\alpha \_$hat, $\beta \_$hat) were tabulated, and it was confirmed that the mean of this distribution matches the observed mean rate of unanimous decisions. 
To check the beta-binomial model, time series were simulated as above, drawing the rate parameter independently from the beta distribution for every year. This model captures the year-to-year variation well. In $57 \%$ of simulated time series, the variance is greater than the true year-to-year variance.

From this model, the probability of observing 43 unanimous cases out of 69 can easily be calculated. Ten thousand rate parameters were drawn from the beta distribution, and, for each, a binomial random variable was drawn from sample size 69. The observed 2013 rate was in the $99.5^{\text {th }}$ percentile of the simulated results, meaning that it was higher than all but $<1 \%$ of the simulated rates, roughly a oncein-a-century occurrence.

Similar tests were done for each of the other three trends: percentage of decisions with dissents, percentage of decisions with concurrences, and percentage of cases decided by a one-vote margin. Results are tabulated below. The "19412012 Variance Percentile" column demonstrates that the variance observed was close to the $50^{\text {th }}$ percentile of the variances generated by the simulations (i.e., $43^{\text {rd }}$ percentile corresponds to the above observation that in $57.2 \%$ of simulated time series, the variance is greater than the true year-to-year variance). In addition to the rate of unanimous decisions being unexpectedly high, the rate of dissents was unexpectedly low (lower than all but $<1 \%$ of the simulated rates). The rate of concurrences and the rate of cases decided by a one-vote margin, on the other hand, are close to the middle of the distribution.

\begin{tabular}{|c|c|c|c|c|}
\hline Trend & $\begin{array}{c}\text { Observed in } \\
2013\end{array}$ & $\begin{array}{c}\text { Beta } \\
\text { Parameters } \\
\left(\alpha \_h a t, \beta \_h a t\right)\end{array}$ & $\begin{array}{c}1941-2012 \\
\text { Variance } \\
\text { Percentile }\end{array}$ & $\begin{array}{l}2013 \text { Rate } \\
\text { Percentile }\end{array}$ \\
\hline $\begin{array}{l}\text { Cases } \\
\text { Decided } \\
\text { Unanimously }\end{array}$ & 43 / 69 & $(33.3,53.0)$ & 43 & 99.5 \\
\hline $\begin{array}{l}\text { Decisions } \\
\text { with } \\
\text { Dissenting } \\
\text { Opinions }\end{array}$ & 27 / 69 & $(32.2,20.9)$ & 39 & 0.7 \\
\hline $\begin{array}{l}\text { Decisions } \\
\text { with } \\
\text { Concurring } \\
\text { Opinions } \\
\end{array}$ & 27 / 69 & $(8.5,14.4)$ & 40 & 56 \\
\hline $\begin{array}{l}\text { Cases } \\
\text { Decided by a } \\
\text { One-Vote } \\
\text { Margin }\end{array}$ & $10 / 69$ & $(4.9,24.4)$ & 28 & 40 \\
\hline
\end{tabular}




\section{Testing the Significance of Changes Between Chief Justices}

The Mann-Whitney $U$ test was used to test whether the changes in percentage of decisions with dissents, percentage of decisions with concurrences, and percentage of cases decided by a one-vote margin were significant. In other words, it tested the null hypothesis that there was no change between the chief justices against the alternative hypothesis that there was an increase or a decrease from one chief justice to his successor. Significance was set at $p<0.01$, to account for the fact that multiple hypotheses were being tested. The $U$-values and results are tabulated below. N1 and N2 indicate each justice's sample size (i.e., the number of terms during which they served as chief justice).

\begin{tabular}{|c|c|c|c|c|c|}
\hline $\begin{array}{l}\text { Justice } \\
\text { Comparison }\end{array}$ & Trend & N1 & N2 & $\boldsymbol{U}$ & $\begin{array}{l}\text { Significance of } \\
\text { Difference }\end{array}$ \\
\hline \multirow[t]{3}{*}{ Marshall/Taney } & $\begin{array}{l}\text { Rate of } \\
\text { Decisions with } \\
\text { Dissents }\end{array}$ & 32 & 28 & 230 & $p<0.01$ \\
\hline & $\begin{array}{l}\text { Rate of } \\
\text { Decisions with } \\
\text { Concurrences }\end{array}$ & 32 & 28 & 328.5 & none \\
\hline & $\begin{array}{l}\text { Rate of Cases } \\
\text { Decided by One- } \\
\text { Vote Margin }\end{array}$ & 32 & 28 & 427 & none \\
\hline \multirow[t]{3}{*}{ Taney/Chase } & $\begin{array}{l}\text { Rate of } \\
\text { Decisions with } \\
\text { Dissents }\end{array}$ & 28 & 9 & 110.5 & none \\
\hline & $\begin{array}{l}\text { Rate of } \\
\text { Decisions with } \\
\text { Concurrences }\end{array}$ & 28 & 9 & 88 & none \\
\hline & $\begin{array}{l}\text { Rate of Cases } \\
\text { Decided by One- } \\
\text { Vote Margin }\end{array}$ & 28 & 9 & 112 & none \\
\hline \multirow[t]{3}{*}{ Chase/Waite } & $\begin{array}{l}\text { Rate of } \\
\text { Decisions with } \\
\text { Dissents }\end{array}$ & 9 & 15 & 36 & none \\
\hline & $\begin{array}{l}\text { Rate of } \\
\text { Decisions with } \\
\text { Concurrences } \\
\end{array}$ & 9 & 15 & 57 & none \\
\hline & $\begin{array}{l}\text { Rate of Cases } \\
\text { Decided by One- } \\
\text { Vote Margin }\end{array}$ & 9 & 15 & 62 & none \\
\hline \multirow[t]{3}{*}{ Waite/Fuller } & $\begin{array}{l}\text { Rate of } \\
\text { Decisions with } \\
\text { Dissents }\end{array}$ & 15 & 22 & 135 & none \\
\hline & $\begin{array}{l}\text { Rate of } \\
\text { Decisions with } \\
\text { Concurrences }\end{array}$ & 15 & 22 & 140 & none \\
\hline & Rate of Cases & 15 & 22 & 98 & none \\
\hline
\end{tabular}




\begin{tabular}{|c|c|c|c|c|c|}
\hline & $\begin{array}{l}\text { Decided by One- } \\
\text { Vote Margin }\end{array}$ & & & & \\
\hline \multirow[t]{3}{*}{ Fuller/Douglass } & $\begin{array}{l}\text { Rate of } \\
\text { Decisions with } \\
\text { Dissents }\end{array}$ & 22 & 11 & 67 & none \\
\hline & $\begin{array}{l}\text { Rate of } \\
\text { Decisions with } \\
\text { Concurrences }\end{array}$ & 22 & 11 & 74.5 & none \\
\hline & $\begin{array}{l}\text { Rate of Cases } \\
\text { Decided by One- } \\
\text { Vote Margin }\end{array}$ & 22 & 11 & 109 & none \\
\hline \multirow[t]{3}{*}{ Douglass/Taft } & $\begin{array}{l}\text { Rate of } \\
\text { Decisions with } \\
\text { Dissents }\end{array}$ & 11 & 9 & 28 & none \\
\hline & $\begin{array}{l}\text { Rate of } \\
\text { Decisions with } \\
\text { Concurrences }\end{array}$ & 11 & 9 & 38 & none \\
\hline & $\begin{array}{l}\text { Rate of Cases } \\
\text { Decided by One- } \\
\text { Vote Margin }\end{array}$ & 11 & 9 & 23.5 & none \\
\hline \multirow[t]{3}{*}{ Taft/Hughes } & $\begin{array}{l}\text { Rate of } \\
\text { Decisions with } \\
\text { Dissents }\end{array}$ & 9 & 11 & 30 & none \\
\hline & $\begin{array}{l}\text { Rate of } \\
\text { Decisions with } \\
\text { Concurrences }\end{array}$ & 9 & 11 & 22 & none \\
\hline & $\begin{array}{l}\text { Rate of Cases } \\
\text { Decided by One- } \\
\text { Vote Margin }\end{array}$ & 9 & 11 & 8 & $p<0.01$ \\
\hline \multirow[t]{3}{*}{ Hughes/Stone } & $\begin{array}{l}\text { Rate of } \\
\text { Decisions with } \\
\text { Dissents }\end{array}$ & 11 & 5 & 0 & $p<0.01$ \\
\hline & $\begin{array}{l}\text { Rate of } \\
\text { Decisions with } \\
\text { Concurrences } \\
\end{array}$ & 11 & 5 & 0 & $p<0.01$ \\
\hline & $\begin{array}{l}\text { Rate of Cases } \\
\text { Decided by One- } \\
\text { Vote Margin }\end{array}$ & 11 & 5 & 4 & $p<0.01$ \\
\hline \multirow[t]{3}{*}{ Stone/Vinson } & $\begin{array}{l}\text { Rate of } \\
\text { Decisions with } \\
\text { Dissents }\end{array}$ & 5 & 7 & 0 & none \\
\hline & $\begin{array}{l}\text { Rate of } \\
\text { Decisions with } \\
\text { Concurrences }\end{array}$ & 5 & 7 & 3 & none \\
\hline & $\begin{array}{l}\text { Rate of Cases } \\
\text { Decided by One- } \\
\text { Vote Margin }\end{array}$ & 5 & 7 & 11 & none \\
\hline \multirow[t]{3}{*}{ Vinson/Warren } & $\begin{array}{l}\text { Rate of } \\
\text { Decisions with } \\
\text { Dissents }\end{array}$ & 7 & 16 & 33 & none \\
\hline & $\begin{array}{l}\text { Rate of } \\
\text { Decisions with } \\
\text { Concurrences }\end{array}$ & 7 & 16 & 51 & none \\
\hline & Rate of Cases & 7 & 16 & 40 & none \\
\hline
\end{tabular}




\begin{tabular}{|l|l|l|l|l|l|}
\hline & $\begin{array}{l}\text { Decided by One- } \\
\text { Vote Margin }\end{array}$ & & & & \\
\hline Warren/Burger & $\begin{array}{l}\text { Rate of } \\
\text { Decisions with } \\
\text { Dissents }\end{array}$ & 16 & 17 & 119 & none \\
\hline $\begin{array}{l}\text { Rate of } \\
\text { Decisions with } \\
\text { Concurrences }\end{array}$ & 16 & 17 & 41 & $p<0.01$ \\
\cline { 2 - 6 } & $\begin{array}{l}\text { Rate of Cases } \\
\text { Decided by One- } \\
\text { Vote Margin }\end{array}$ & 16 & 17 & 77 & none \\
\hline Burger/Rehnquist & $\begin{array}{l}\text { Rate of } \\
\text { Decisions with } \\
\text { Dissents }\end{array}$ & 17 & 19 & 70 & $p<0.01$ \\
\cline { 2 - 6 } & $\begin{array}{l}\text { Rate of } \\
\text { Decisions with } \\
\text { Concurrences }\end{array}$ & 17 & 19 & 161 & none \\
\cline { 2 - 6 } & $\begin{array}{l}\text { Rate of Cases } \\
\text { Decided by One- } \\
\text { Vote Margin }\end{array}$ & 17 & 19 & 110.5 & none \\
\hline Rehnquist/Roberts & $\begin{array}{l}\text { Rate of } \\
\text { Decisions with } \\
\text { Dissents }\end{array}$ & 19 & 9 & 80.5 & none \\
\cline { 2 - 6 } & $\begin{array}{l}\text { Rate of } \\
\text { Decisions with } \\
\text { Concurrences }\end{array}$ & 19 & 9 & 77 & none \\
\hline $\begin{array}{l}\text { Rate of Cases } \\
\text { Decided by One- } \\
\text { Vote Margin }\end{array}$ & 19 & 9 & 80 & none \\
\hline
\end{tabular}

